\title{
Influence of oil and gas field operations on spatial and temporal distributions of atmospheric non-methane hydrocarbons and their effect on ozone formation in winter
}

\author{
R. A. Field ${ }^{1}$, J. Soltis ${ }^{1}$, M. C. McCarthy ${ }^{2}$, S. Murphy ${ }^{1}$, and D. C. Montague ${ }^{1}$ \\ ${ }^{1}$ Department of Atmospheric Science, University of Wyoming, Laramie, WY, USA \\ ${ }^{2}$ Sonoma Technology Inc., Petaluma, CA, USA \\ Correspondence to: R. A. Field (rfield1@uwyo.edu)
}

Received: 16 September 2014 - Published in Atmos. Chem. Phys. Discuss.: 30 September 2014

Revised: 11 February 2015 - Accepted: 13 March 2015 - Published: 31 March 2015

\begin{abstract}
Emissions from oil and natural gas development during winter in the Upper Green River basin of Wyoming are known to drive episodic ozone $\left(\mathrm{O}_{3}\right)$ production. Contrasting $\mathrm{O}_{3}$ distributions were observed in the winters of 2011 and 2012, with numerous episodes (hourly $\mathrm{O}_{3} \geq 85 \mathrm{ppbv}$ ) in 2011 compared to none in 2012. The lack of $\mathrm{O}_{3}$ episodes in 2012 coincided with a reduction in measured ambient levels of total non-methane hydrocarbons (NMHC). Measurements of speciated NMHC, and other air quality parameters, were performed to better understand emission sources and to determine which compounds are most active in promoting $\mathrm{O}_{3}$ formation. Positive matrix factorization (PMF) analyses of the data were carried out to help achieve these goals. PMF analyses revealed three contributing factors that were identified with different emission source types: factor 1, combustion/traffic; factor 2, fugitive natural gas; and factor 3, fugitive condensate. Compositional signatures of the three contributing factors were identified through comparison with independently derived emission source profiles. Fugitive emissions of natural gas and of condensate were the two principal emission source types for NMHC. A water treatment and recycling facility was found to be a significant source of NMHC that are abundant in condensate, in particular toluene and $m+p$-xylene. Emissions from water treatment have an influence upon peak $\mathrm{O}_{3}$ mixing ratios at downwind measurement sites.
\end{abstract}

\section{Introduction}

Oil and natural gas (O\&NG) production in the US has grown significantly over the past decade and is expected to continue to grow through 2020 (US EIA (Energy Information Administration), 2014). Improved production methods such as hydraulic fracturing and horizontal drilling technologies have enabled O\&NG producers to access reservoirs that previously were economically infeasible (US Department of Energy, 2009). The US EIA (2012) estimates an increase in shale gas production from 5.0 trillion cubic feet (tcf) per year in 2010 to $13.6 \mathrm{tcf}$ per year by 2035 , when shale gas is expected to account for half of total US gas production. Some of this new development is scheduled to take place in Wyoming, an energy rich state, ranked second in the US in total energy production for the 2012 data. In terms of proven natural gas reserves in the US for 2009, the Pinedale Anticline Project Area (Pinedale Anticline) and the Jonah Field, both in the Upper Green River basin (UGRB) of Sublette County, Wyoming, rank 3rd and 7th, respectively. These fields are both in the top 100 of proven US reserves for oil, with the Pinedale Anticline ranked 49th and Jonah ranked 65th (US EIA, 2010).

Adverse atmospheric impacts of the development and operation of O\&NG fields include emissions of methane, a potent greenhouse gas (Allen et al., 2013; Karion et al., 2013; Brandt et al., 2014; Caulton et al., 2014). A further concern is degraded local air quality, which can impact human health and well-being (Adgate et al., 2014; Colburn et al., 2014; McKenzie et al., 2012, 2014) through the emission of a range of air toxics and other pollutants (Pétron et al., 2012; Field et 
al., 2014; Helmig et al., 2014; Moore et al., 2014; Warneke et al., 2014) that can lead to the subsequent photochemical production of ozone $\left(\mathrm{O}_{3}\right)$ (Edwards et al., 2013; Gilman et al., 2013; Oltmans et al., 2014).

Until recently, the formation of high levels of $\mathrm{O}_{3}$ in surface air was considered to be a summertime phenomenon in polluted urban areas. The discovery of $\mathrm{O}_{3}$ mixing ratios exceeding $100 \mathrm{ppbv}$ in 2005 in the rural UGRB in winter (Schnell et al., 2009), well above the pre-2008 National Ambient Air Quality Standard (NAAQS) of 85 ppbv for the fourth highest $8 \mathrm{~h}$ average, was therefore unexpected. Similar wintertime high $\mathrm{O}_{3}$ episodes have subsequently reoccurred in the UGRB and, more recently, have also been observed in the nearby Uintah Basin of Utah. At both locations, $\mathrm{O}_{3}$ formation has been directly linked to emissions from O\&NG sources (Schnell et al., 2009; Martin et al., 2011; Oltmans et al., 2014), although specific details of the role played by non-methane hydrocarbons (NMHC) were initially not fully appreciated. Studies show that development of elevated $\mathrm{O}_{3}$ mixing ratios requires significant snow cover to facilitate both a high actinic flux and the formation of strong persistent shallow inversions. Inversions lead to the build up of adequate amounts of volatile organic compounds (VOCs) and oxides of nitrogen $\left(\mathrm{NO}_{\mathrm{x}}\right)$, the gaseous precursors of $\mathrm{O}_{3}$. Episodes are most frequent later in winter (January-March) when insolation is increasing, but before snow cover decreases.

Since 2005, additional air quality network and meteorological monitoring stations have been deployed throughout the UGRB to determine the extent of $\mathrm{O}_{3}$ episodes and their characteristics. Modeling studies have also been carried out (Carter and Seinfeld, 2012; Rappenglück et al., 2014). They point to the need for more definitive information on both the distribution and specific identity of $\mathrm{O}_{3}$ precursor VOC compounds. These monitoring and modeling studies have led to significant progress in understanding the mechanisms and critical reaction pathways for wintertime $\mathrm{O}_{3}$ formation, but questions remain. Notwithstanding the apparent importance of $\mathrm{HONO}$ for $\mathrm{O}_{3}$ production (Rappenglück et al., 2014), the exact roles played by nitrogen-containing compounds and many individual VOCs, and, in consequence, the behavior of their radical derivatives, remain to be clarified. Many of these questions have recently been answered for the Uintah Basin (Edwards et al., 2013, 2014), but the similarities and differences of wintertime $\mathrm{O}_{3}$ formation chemistry in the different basins remains to be determined.

When wintertime ozone, measured at Wyoming Department of Environmental (WDEQ) monitoring stations in 2005 and 2008 in the UGRB, was first reported by Schnell et al. (2009), the subtleties of photochemical production mechanisms were not clear. Modeling studies of 2011 wintertime ozone in the UGRB by Carter and Seinfeld (2012) and Rappenglück et al. (2014) have demonstrated that ozone production is critically dependent upon NMHC. These studies used some data from the University of Wyoming Boulder South
Road (BSR) site as model input together with other available data in the UGRB. Here we present the entire speciated NMHC data set from BSR and explore intra-species correlations to investigate sources. Rather than photochemical modeling of ozone, we attempt to reconcile contributing emission sources with observed speciated NMHC. We also show the relationship of species sub-groups to $\mathrm{O}_{3}$ during days with active wintertime photochemistry. Specifically, in this study we identify the most important speciated $\mathrm{NMHC}$ for $\mathrm{O}_{3}$ formation, and by using positive matrix factorization (PMF) source apportionment (Brown et al., 2007; Buzcu and Fraser, 2008; McCarthy et al., 2013) determine the relative contributions of various emission sources to observed hydrocarbon levels.

\section{Methodology}

Figure 1 shows well locations and monitoring locations in the Pinedale Anticline and Jonah Field developments. Table S2 in the Supplement gives more details of these locations and other sampling sites employed in the study. Summary statistics for the BSR site are given in Table S4. The UGRB, at an elevation of approximately $2150 \mathrm{~m} \mathrm{~m}$.s.l., is enclosed by the Wyoming mountain range to the west, the Gros Ventre range to the north, and the Wind River mountains to the northeast. To the south it broadens and opens onto lower elevation plains and the Interstate 80 corridor. It is located in Sublette County, Wyoming, where the population density, as reported by the US Census Bureau (2010), is a sparse 2.1 people per square mile $\left(0.8\right.$ per $\left.\mathrm{km}^{2}\right)$. As the Pinedale Anticline and Jonah Field developments are both ranked within the top 10 of wet gas fields for proven reserves in the US (US EIA, 2010), the area has a high density of O\&NG wells. Pollutant emissions in the UGRB are almost entirely from O\&NG activities (WDEQ, 2014a) with minimal contributions from other sources (Schnell et al., 2009).

Measurements characterizing air quality in the UGRB were carried out in and around the Pinedale Anticline. The principal monitoring site was at BSR, a location that experiences surface air containing relatively well-mixed trace gases representative of emissions from a variety of nearby O\&NG development sources. This site was first used in 2009 as a comparative site (Soltis and Field, 2009) to the WDEQ Boulder site (BLDR). As shown in Fig. 1 BSR (2142 m m.s.l.) is located about $5 \mathrm{~km}$ to the southeast of BLDR (2162 m m.s.l.) at a slightly lower elevation. Measurements of $\mathrm{O}_{3}$, reactive nitrogen compounds $\left(\mathrm{NO} / \mathrm{NO}_{2} / \mathrm{NO}_{\mathrm{x}}\right)$, total $\mathrm{NMHC}$, methane $\left(\mathrm{CH}_{4}\right)$, and carbon monoxide $(\mathrm{CO})$ mixing ratios, and standard meteorological parameters, were carried out continuously at BSR during the winters of 2010/2011 and 2011/2012. Table S1 in the Supplement lists the measurement uncertainties of these parameters and details of instrumentation employed.

Total NMHC measurements employed a Thermo Scientific 55i back-flush gas chromatographic system that provides 


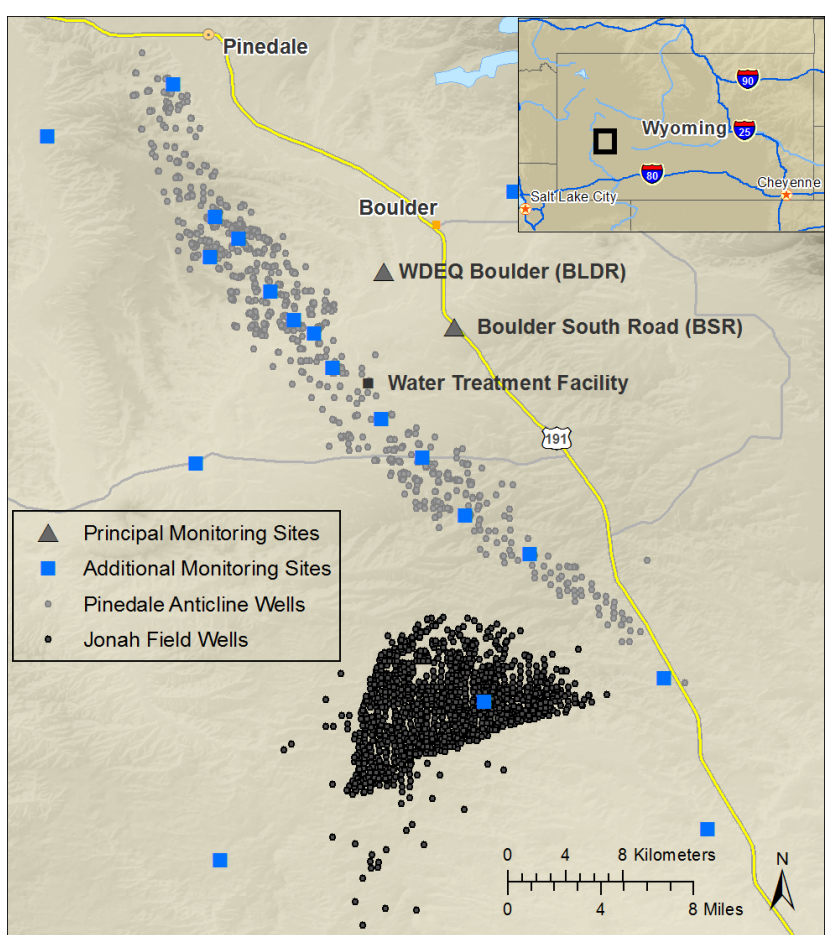

Figure 1. Map of study area including principal monitoring sites and locations of oil and natural gas wells within the Jonah Field and the Pinedale Anticline.

direct measurements of $\mathrm{CH}_{4}$ and total NMHC. The backflush method provides a direct measurement of total NMHC concentrations and this allows accurate and precise measurement of low levels of total NMHC even if methane is at a much higher concentration.

The total NMHC peak consists of $\mathrm{C}_{2}$ to $\mathrm{C}_{11}$ compounds, with the possibility of some $\mathrm{C}_{12}$ compound being captured. This upper range is due to sample losses on the walls of transport tubing with the analyzer designed for ambient sampling without a heated inlet (Francis, 2014). While the Thermo Scientific model 55i analyzer measurement of total NMHC includes VOC containing halogens, nitrogen and oxygen, the sensitivity is anticipated to be lower for these classes compared to hydrocarbons. All compounds with C-bonds are detected, with a generally greater relative sensitivity for compounds with a higher number of $\mathrm{C}-\mathrm{H}$ bonds. While sensitivity is proportional to carbon number, the replacement of C-H bonds with other functional groups typically results in a decrease in sensitivity.

\subsection{Speciated NMHC analyses}

Hourly online measurements of speciated NMHC were performed at BSR during 2010/2011. Discontinuous speciated NMHC measurements at BSR in 2011/2012 and 2012/2013 were carried out using canister sampling (Entech silonite $6 \mathrm{~L}$ canisters). Similar discontinuous measurements were made at other locations in all three winter periods (Fig. 1). Individual NMHC selected for this study are listed in Table 1. They include 15 alkanes, 10 alkenes, two alkynes and 10 aromatics. In 2010/2011 and 2011/2012, canister samples from locations other than BSR were collected for $24 \mathrm{~h}$ periods, except when co-located diffusive samplers were concurrently deployed, when sample times were extended to $72 \mathrm{~h}$. The results of diffusive sampling are the subject of a separate analysis to be reported elsewhere. Canister sampling duration was controlled using an Entech CS1200E flow regulation system. Sites close to emission sources were included in 2011/2012 and in 2012/2013. Table S2 provides geographic coordinates of the monitoring sites and lists the number of samples at each site. Additional details are given elsewhere (Soltis and Field, 2011a, b, 2012a, b).

Speciated NMHC analyses were carried out using a Perkin Elmer (PE) $\mathrm{O}_{3}$ Precursor Analyzer (OPA) system that incorporates a Peltier cooled inlet adsorption sample concentrator within a TurboMatrix 300 Thermal Desorption system, a Nafion ${ }^{\circledR}$ dryer to remove water vapor, and a PE Clarus 500 Gas Chromatograph (GC) equipped with flame ionization detectors (FIDs). The chromatograph utilizes two parallel columns for the separate analysis of lower $\left(\mathrm{C}_{6}\right.$ to $\left.\mathrm{C}_{12}\right)$ and more $\left(\mathrm{C}_{2}\right.$ to $\left.\mathrm{C}_{6}\right)$ volatile fractions in the sample. It was operated using ultrapure helium as the carrier gas. Further details of the OPA system are given elsewhere (Broadway and Tipler, 2012). During 2010/2011 canister samples were analyzed at the BSR field site. Consistent quality of the two sampling methods was ensured through recovery testing using span and zero gases. In 2011/2012 and 2012/2013, only canisters were used for sample collection, which were subsequently analyzed with minimal delay by the OPA at the University of Wyoming, using the same analytical protocol and data processing methods as those employed at BSR, thereby achieving equivalent analytical quality. Instrument calibrations were conducted with a custom trace gas standard mixture supplied by Apel-Riemer Environmental, Inc. The mole fraction of reported compounds ranged from 3.6 to 44.6 ppbv. Calibration curves that encompassed the entire measurement range encountered in the field were achieved through varying the trapping time for analysis. Table S1 in the supplementary material lists the measurement uncertainties calculated for this study. Further details of monitoring sites, experimental sampling protocols, analytical instrumentation, and analysis techniques are given in the supplementary material, and by Soltis and Field (2011a, b, 2012a, b).

\section{Data processing}

The output data from the OPA were processed and validated with a data management system provided by Ricardo-AEA, Ltd., UK. This system, used by the UK Automatic Hydrocarbon Network for more than 20 years (Dollard et al., 1995), analyzes batches of multiple chromatograms to yield an output file containing compiled time-stamped validated data that 
Table 1. Speciated NMHC measured with the Perkin Elmer Ozone Precursor Analyzer.

\begin{tabular}{|c|c|c|}
\hline Alkane & Alkene (\&Alkyne) & Aromatic \\
\hline Ethane & ethene (ethylene) & benzene \\
\hline Propane & propene (propylene) & toluene \\
\hline Butane ( $n$-butane) & trans-but-2-ene ( $t$-2-butene) & ethylbenzene \\
\hline 2-Methylpropane ( $i$-butane) & but-1-ene (1-butene) & $m+p$-xylene \\
\hline Pentane ( $n$-pentane) & cis-but-2-ene ( $c$-2-butene $)$ & $o$-xylene \\
\hline 2-Methylbutane ( $i$-pentane) & 1,3-butadiene & styrene \\
\hline Cyclopentane & pent-1-ene (1-pentene) & 1,2,3-trimethylbenzene* \\
\hline Hexane ( $n$-hexane) & trans-pent-2-ene ( $t$-2-pentene) & 1,2,4-trimethylbenzene* \\
\hline 2-Methylpentane ( $i$-hexane) & cis-pent-2-ene ( $c$-2-butene) & 1,3,5-trimethylbenzene* \\
\hline 3-Methylpentane & 2-methyl-1,3-butadiene (isoprene) & \\
\hline \multicolumn{3}{|l|}{ Heptane ( $n$-heptane) } \\
\hline Octane ( $n$-octane $)$ & ethyne (acetylene) & \\
\hline Cyclohexane & prop-1-yne (propyne) & \\
\hline \multicolumn{3}{|l|}{ Nonane } \\
\hline Decane* & & \\
\hline
\end{tabular}

* not reported during 2011-2012 or 2012-2013; during 2010-2011 indicative only.

include peak areas, widths, and retention times, for identified chromatogram eluents in each analyzed sample (Dernie and Dumitrean, 2013). Initialization of the processing software requires template calibration information that provides comparator data for the input chromatograms, which in this study were grouped into 1-month-long periods. Proprietary artificial intelligence (neural network) pattern recognition MatchFinder ${ }^{\circledR}$ software was employed to identify specific hydrocarbon peaks in the monthly batch analysis output files. Quality assurance and control procedures developed for the UK Automatic Hydrocarbon Network are then applied to ensure that peaks are correctly identified and without co-elution or peak merging issues (Derwent et al., 2014).

Conversion of chromatogram raw peak areas to mixing ratios was carried out using response factors derived from calibration gas mixtures. Calibration responses were proportional to carbon number (from $\mathrm{C}_{2}$ to $\mathrm{C}_{10}$ ) with calculated accuracies given in Table $\mathrm{S} 1$. Response factor differences were observed, however, for ethyne, isoprene, and 1,3-butadiene, due to slow wall-induced heterogeneous loss of these compounds within the calibration gas mixture cylinder. Consequently, relative response factors were used to calculate mixing ratios of these gases. In addition, chromatographic problems resulting from measurable "carry over" effects for decane, and the trimethylbenzenes in successive analyses, resulted in the derived mixing ratios for these compounds being removed from validated data sets used for subsequent interpretive analyses of ambient atmospheric behavior. The quality of validated data was demonstrated through a blind test of an unknown mixture with the support of the National Center for Atmospheric Research (NCAR) shown in Table S3.

\subsection{Positive matrix factorization analysis of speciated NMHC}

Positive matrix factorization (PMF) analyses of the BSR speciated NMHC data have been carried out to determine emission source characteristics and contributions. This analysis technique, developed by Paatero and Tapper (1994) and Paatero (1997), solves a bilinear receptor model that assumes that the data set being analyzed is composed of contributions from a small number of factors, each with an unknown but constant source profile, that vary in magnitude with time. PMF analysis aims to evaluate the optimum value of the chemical profile of each factor, and the mass contributions from each factor. It provides results as factors, or groups of compounds, each of which effectively constitutes a pattern or signature of an emission source or group of sources. The final output is analyzed to determine how well modeled results reproduce the input data by examining the residuals for each compound, scatter plots for predicted and observed compound correlations, and mass recovery. The multivariate factor analysis EPA PMF tool, widely applied to ambient air quality data (Poirot et al., 2001; Song et al., 2001), was used for analysis of the BSR speciated NMHC data for the period October 2010 through March 2011. Uncertainties in the solution are estimated using a bootstrapping technique (Efron, 1982; Efron and Tibshirani, 1993; Norris et al., 2008). Each resampled data set is decomposed into profile and contribution matrices using PMF, and the results of each bootstrap run are then compared with the base run. If the original, base-run factors are consistently found or mapped with the resampled bootstrap runs, the factors are considered to be robust and the data are not over-fit.

PMF receptor modeling relies on data with known quality and accuracy, as measured by uncertainty. Uncertainties 
were calculated on both an absolute and relative basis to account for method detection limits and peak fitting imprecision. All speciated NMHC were assigned a conservative base uncertainty of $0.1 \mathrm{ppbv}$, plus $3 \%$ of the measured value of a given sample. For example, a measured value of $1 \mathrm{ppbv}$ would have an uncertainty of 0.13 ppbv, while a measured value of $10 \mathrm{ppbv}$ would have an uncertainty of $0.4 \mathrm{ppbv}$. Compounds were removed from the analysis if their signalto-noise $(S / N)$ ratios were below 1.3. Application of this criterion removed 1-butene, 1,3-butadiene, $t$-2-butene, $c$-2butene, 1-pentene, isoprene, propyne, styrene, and propene from the analyses. Four consecutive samples on 26 November 2010 were also excluded from analysis because they contained high outlier values for toluene with values ranging from $28.5 \mathrm{pppv}$ to $274.4 \mathrm{ppbv}$. Three outlier values for $\mathrm{CO}$ were removed on 23 November 2010. These unrepresentative samples would not be effectively modeled using the PMF statistical technique. In addition to speciated NMHC, hourly data for total NMHC, background corrected $\mathrm{CO}$, and background corrected $\mathrm{CH}_{4}$, were included in the analyses. $\mathrm{NO}_{\mathrm{x}}$ is not included in the PMF analysis presented here as the focus of this study is source apportionment of speciated NMHC, and preliminary analyses revealed that $\mathrm{NO}_{\mathrm{x}}$ was the only parameter in a separate factor.

\section{Results and discussion}

\subsection{Temporal variation of $\mathrm{O}_{3}$, total $\mathrm{NMHC}$ and $\mathrm{NO}_{\mathrm{x}}$}

WDEQ ozone measurements at the BLDR site commenced in 2005 and have been performed continuously since then. They reveal numerous occasions when hourly averaged $\mathrm{O}_{3}$ levels were at or above $75 \mathrm{ppbv}$, and several occurrences during 2005, 2008, and 2011 when fourth highest $8 \mathrm{~h}$ average values also exceeded 75 ppbv. In 2012, the UGRB was designated a non-attainment zone for the National Ambient Air Quality Standard for $\mathrm{O}_{3}$. In 2011, daily $8 \mathrm{~h}$ ozone averages exceeded 75 ppbv at BLDR on 8 days. Similar exceedances occurred in 2011 at other UGRB WDEQ sites, albeit less frequently and at slightly lower $\mathrm{O}_{3}$ levels. During 2011, measurements at BSR, also close to the Pinedale Anticline O\&NG development (see Fig. 1), corroborated elevated ozone measurements at BLDR. At BSR, seven exceedances were observed in 2011. Of note however, is that in contrast to the significant number of ozone episodes in 2011, there were only 3 days in 2012 during the January to March "ozone season" when the hourly average ozone mixing ratio exceeded 75 ppbv, and a complete absence of days with non-compliant $8 \mathrm{~h}$ ozone averages. Figure 2 shows plots of hourly averaged mixing ratios of $\mathrm{O}_{3}, \mathrm{NO}_{\mathrm{x}}$, and total $\mathrm{NMHC}$ at BSR during the months January to March in 2011 and 2012. It is evident that both $\mathrm{O}_{3}$ episodes (hourly $\mathrm{O}_{3} \geq 85 \mathrm{ppbv}$ ) and high total NMHC values are significantly more frequent in 2011 than in 2012, while $\mathrm{NO}_{\mathrm{x}}$ levels in these years are similar.
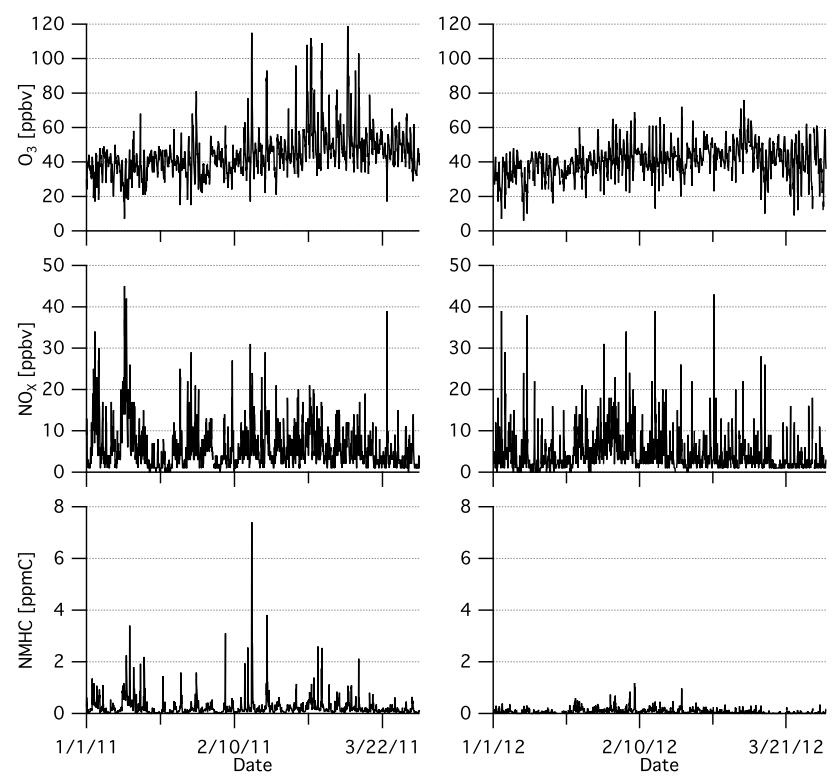

Figure 2. Time series of $\mathrm{O}_{3}, \mathrm{NO}_{\mathrm{x}}$, and $\mathrm{NMHC}$ at Boulder South Road (BSR) for the period January through March during 2011 and 2012.

Species mixing ratios are influenced by their emission and/or formation rate(s), their removal rate, and by meteorological factors affecting dilution and dispersion. If meteorology were the only factor resulting in the year-to-year $\mathrm{NMHC}$ and $\mathrm{O}_{3}$ differences shown in Fig. 2, then $\mathrm{NO}_{\mathrm{x}}$ behavior should exhibit a similar pattern as NMHC. Observations at BLDR show similar behavior as those at BSR (MSI, 2012), with 16 hourly values of total NMHC greater than $2 \mathrm{ppmC}$ in 2011 compared to none in 2012. In addition, a reduction in the average NMHC mixing ratio for the January to March period was found at both sites, from $0.34 \mathrm{ppmC}$ in 2011 to $0.19 \mathrm{ppmC}$ in 2012 at BLDR, and from 0.23 to $0.07 \mathrm{ppmC}$ at BSR. For $\mathrm{NO}_{\mathrm{x}}$, similar reductions in the analogous mixing ratios were also observed, from 5 to 2 ppbv at BLDR and from 6 to 4 ppbv at BSR. These mixing ratio reductions may be linked to estimated emissions reductions of $\sim 20$ and $\sim 50 \%$ for VOCs and $\mathrm{NO}_{\mathrm{x}}$ respectively, reported in the winter emission inventory for Sublette County, from 2011 to 2012 (WDEQ, 2014a).

Snow cover and meteorological conditions, including temperature and wind speeds, at both BLDR and BSR in 2011 and 2012 were broadly similar, with no significant differences, suggesting that neither factor can solely account for the observed mixing ratio differences (MSI, 2012). Moreover, $8 \mathrm{~h}$ average mixing ratio $\mathrm{O}_{3}$ episodes were not only absent in 2012, but also in 2013 and 2014, at all UGRB sites, even though apparently favorable conditions (snow cover extent, $700 \mathrm{mb}$ pressure, temperature, and wind speed) for $\mathrm{O}_{3}$ formation prevailed (MSI, 2012, 2013, 2014).

The weight of evidence suggests that the observed decreases in $\mathrm{NMHC}$ and $\mathrm{NO}_{\mathrm{x}}$ mixing ratios and the concomi- 
tant lack of $\mathrm{O}_{3}$ episode occurrence since 2011, likely result primarily from reduced $\mathrm{O}_{3}$ precursor emission rates. However, factors associated with snow cover and meteorological conditions cannot be entirely discounted, because they can strongly affect ozone production rates. The influence of meteorology is recognized to affect year-to-year variability of $\mathrm{O}_{3}$ levels. A lack of $\mathrm{O}_{3}$ episodes in 2009 was for example linked with the absence of snow cover.

\section{2 $\mathrm{O}_{3}$ variations at $\mathrm{BSR}$ and $\mathrm{BLDR}$}

Similar $\mathrm{O}_{3}$ mixing ratios were observed at BSR and BLDR in 2009, 2010, 2011 and 2012 during spring, summer, and fall. In November and December 2011, the average difference of hourly $\mathrm{O}_{3}$ measurements at the two sites is $3 \mathrm{ppbv}$, and when values at BLDR exceed $40 \mathrm{ppbv}$, only three measurements differ from those at BSR by more than $10 \mathrm{ppbv}$, none of which occur during afternoon hours. Similar behavior is found in November and December 2010. Afternoon maximum $\mathrm{O}_{3}$ mixing ratios at the two sites are invariably similar. By contrast, the behavior observed in months associated with wintertime $\mathrm{O}_{3}$ is different. For example, in February and March 2012, when $\mathrm{O}_{3}$ values exceeded $40 \mathrm{ppbv}$ at BLDR, 11 of the 12 measurements with a difference of greater than 10 ppbv are in the afternoon, 4 of which occur when $\mathrm{O}_{3}$ is higher than $70 \mathrm{ppbv}$ at BLDR. Wintertime differences were even more apparent in February and March 2011, when 91 afternoon hours differed by more than $10 \mathrm{ppbv}$, with $73 \mathrm{oc}-$ curring when $\mathrm{O}_{3}$ was higher than 70 ppbv at BLDR.

In the winter of $2011, \mathrm{O}_{3}$ episodes (average hourly $\mathrm{O}_{3} \geq 85 \mathrm{ppbv}$ ) were observed on 13 days in the UGRB. Diurnal variations in $\mathrm{O}_{3}$ mixing ratio observed at $\mathrm{BSR}$ and at BLDR (WDEQ, 2014b), located some $5 \mathrm{~km}$ to the northwest, are illustrated by the $24 \mathrm{~h}$ time-series plots on four days in 2011 in Fig. 3. These plots indicate the effect of variability in background levels, local production, and transport of $\mathrm{O}_{3}$ to the different measurement sites. On 26 February 2011, when $\mathrm{BSR}_{3}$ mixing ratios increase by $\sim 60 \mathrm{ppbv}$, peak $\mathrm{O}_{3}$ at BSR exceeds that at BLDR by $\sim 20 \mathrm{ppbv}$. However, on 1 March 2011, $\mathrm{O}_{3}$ increased by $\sim 120 \mathrm{ppbv}$ at BLDR, but only by $\sim 70 \mathrm{ppbv}$ at BSR. Similar behavior is evident on 2 March 2011. Both of these days are associated with light southwesterly winds. By contrast on 15 March 2011, $\mathrm{O}_{3}$ mixing ratios behave similarly at both BLDR and BSR, except for a short $\sim 20 \mathrm{ppbv}$ increase at BSR around 14:00. $\mathrm{O}_{3}$ behavior for all 13 episode days are given in Fig. S5.

Figure 2 plots suggest that high $\mathrm{O}_{3}$ levels in 2011 are promoted by relatively high levels of total NMHC at relatively moderate $\mathrm{NO}_{\mathrm{x}}$ levels. Understanding the observed differences in $\mathrm{O}_{3}$ episode variability is perhaps best achieved by examining the detailed composition and mixing ratios of the constituent NMHC, together with the concomitant levels of $\mathrm{NO}_{\mathrm{x}}$, at the two sites.
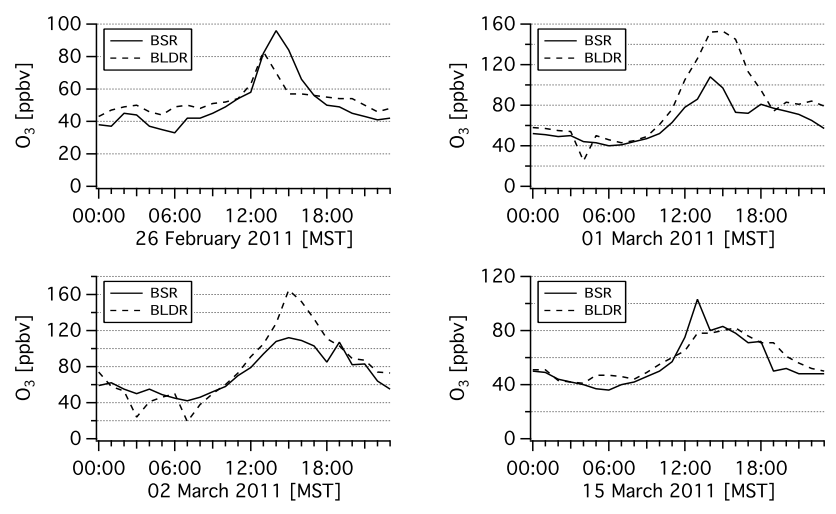

Figure 3. $\mathrm{O}_{3}$ mixing ratios during four episodes at Boulder sites February to March 2011.

\subsection{Relationship of $\mathrm{O}_{3}$ to $\mathrm{NMHC}$ and $\mathrm{NO}_{\mathrm{x}}$}

Surface NMHC measurements from October 2010 to March 2011 show diurnal and seasonal variations, with the highest values during the coldest months and at night. Low surface temperatures in winter are associated with nocturnal radiation inversions that lead to pollutant trapping and accumulation, and consequential elevated mixing ratios (Schnell et al., 2009; Oltmans et al., 2014).

An assessment of the fractional contribution of OPA detected hydrocarbons to the total NMHC measured by the Thermo 55i instrument (Table S1) was undertaken to understand the utility of total NMHC measurements, and to determine the contributions of speciated NMHC selected for this study. To achieve these aims, a mass balance comparison of the total NMHC to the sum of the OPA identified speciated NMHC $\left(\mathrm{C}_{2}\right.$ to $\left.\mathrm{C}_{8}\right)$ was performed. Total integrated NMHC measured by the Thermo $55 \mathrm{i}$ includes both hydrocarbons and their halogenated, oxygenated, and nitrogen-containing derivatives, up to $\mathrm{C}_{11}$ compounds. The mass balance comparison between total NMHC and the sum of the OPA identified speciated NMHC is shown in Fig. S6, for the period October 2010 to March 2011. A simple linear regression fit to the 2320 data points yields a best fit line of slope 0.57 and a coefficient of determination $\left(R^{2}\right)$ of 0.90 . While there is a strong correlation between the two NMHC data sets, using only identified OPA NMHC omits $\sim 43 \%$ of the carbonaceous material included in the total NMHC measurement. Diurnal analyses reveal no significant differences by time of day. A second analogous comparison was carried out in which all of the unreported and unidentified carbonaceous material detected by the OPA was included in the NMHC summation. This additional material increased the mass from identified $\mathrm{C}_{2}-\mathrm{C}_{6}$ aliphatic hydrocarbons by a factor of 1.1, and that from identified $\mathrm{C}_{7}-\mathrm{C}_{8}$ aliphatic and $\mathrm{C}_{6}-\mathrm{C}_{9}$ aromatic compounds by a factor of 2.0. The augmented summation of speciated NMHC mass resulted in both the slope and $R^{2}$ values of the regression line increasing, to 0.88 and 0.92 respec- 
tively. Measurement uncertainties, as outlined in Table S1, could account for the mass deficit implied by a regression fit slope less than unity.

Wintertime measurements at BLDR from 2007 to 2014 reveal contributions of $\sim 70 \%$ for alkanes, $\sim 15 \%$ for aromatics, and $>5 \%$ each for naphthalenes, alkenes and oxygenates to the observed VOCs (MSI, 2014). These measurements suggest that hydrocarbon classes dominate the total mass of VOC in the UGRB. Contributions of oxygenated VOCs not detected by the OPA are likely to be small, even though it is likely that they play an important role in wintertime photochemistry (Edwards et al., 2014), a contention supported by measurements of carbonyl compounds at BLDR that suggests formaldehyde and acetaldehyde contribute significantly to VOC reactivity (MSI, 2014).

Identified $\mathrm{C}_{2}$ to $\mathrm{C}_{9}$ compounds contributing most to the total carbon NMHC mass measured by the OPA at BSR, namely ethane $(26 \%)$, propane $(15 \%)$, toluene $(11 \%), m+$ $p$-xylene and $p$-xylene (7\%), $i$-butane $(5 \%)$, and $n$-butane (5\%), make up $69 \%$ of the identified carbonaceous mass. Similarly, analyses of 16 canister samples collected at BLDR in the winters of 2011/2012 and 2012/2013, during the Upper Green winter $\mathrm{O}_{3}$ studies (UGWOSs) (MSI, 2012, 2013) show that the three most important contributors are ethane $(21 \%)$, propane $(19 \%)$, and toluene $(8 \%)$. The same dominant hydrocarbons are found at both measurement sites indicating that the hydrocarbon composition at BSR and BLDR is similar, as expected given their close proximity. This examination of the relative contributions of identified hydrocarbons showed that while missing mass is related to heavier NMHC, the most abundant NMHC in the $\mathrm{C}_{2}$ to $\mathrm{C}_{8}$ range are reported.

Variations in the measured $\mathrm{O}_{3}$ mixing ratio together with changes in total $\mathrm{NMHC}$ and $\mathrm{NO}_{\mathrm{x}}$ at BSR are shown in Fig. 4, constructed from hourly averaged observations obtained between 11:00 and 20:00 during the three-month winter period from January to March 2011. Highest $\mathrm{O}_{3}$ mixing ratios are associated with total NMHC mixing ratios above $0.2 \mathrm{ppmC}$, when $\mathrm{NO}_{\mathrm{x}}$ mixing ratios are 6-20 ppbv, and decrease significantly as the mixing ratios of these precursors decline. As noted previously, $\mathrm{O}_{3}$ production only occurs when actinic flux levels are high, and when this requirement is not met, $\mathrm{O}_{3}$ mixing ratios remain low, irrespective of precursor concentrations. The data shown in Fig. 4 are undoubtedly influenced by a number of environmental parameters including meteorology, actinic flux intensity, and NMHC composition. An analogous plot constructed using BLDR measurements is shown in the supplementary information (Fig. S7). It exhibits the same trends evident in Fig. 4, but shows greater variability of $\mathrm{NO}_{\mathrm{x}}$ for high ozone values (80-120 ppbv). Thus, unlike at BSR, high $\mathrm{O}_{3}$ mixing ratios are occasionally observed at BLDR when $\mathrm{NO}_{\mathrm{x}}$ is low. Reported $\mathrm{NO}_{\mathrm{x}}$ mixing ratios at BLDR frequently display erratic hour-to-hour variability throughout the period January to March 2011, during periods of both high and low $\mathrm{O}_{3}$ mixing ratio. This suggests

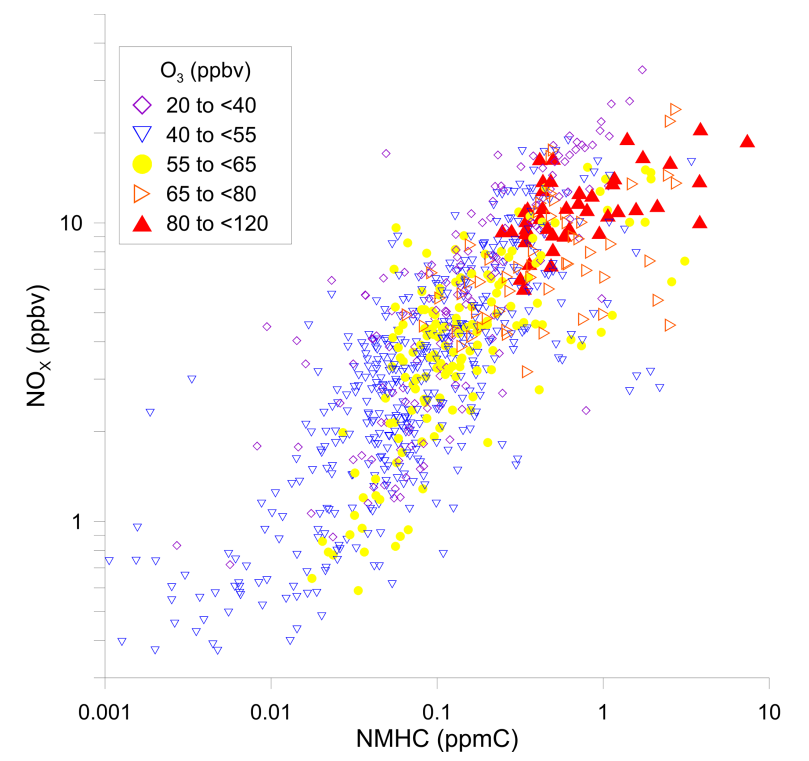

Figure 4. $\mathrm{O}_{3}$, $\mathrm{NMHC}$ and $\mathrm{NO}_{\mathrm{x}}$ during daytime (11:00 to 20:00) for the period January to March 2011 at Boulder South Road (BSR).

that the measurement uncertainties at BLDR may be larger than at BSR, and allows for the possibility that the greater scatter evident in Fig. S7 compared to Fig. 4 results from these uncertainty differences. The figures reinforce the notion that high NMHC precursor mixing ratios are a necessary but insufficient condition for $\mathrm{O}_{3}$ formation. Other factors, as outlined above, must also be favorable. Thus for many daytime hours, there are elevated precursor levels without high $\mathrm{O}_{3}$, suggesting that assuming constant emissions rates, favorable meteorological conditions required for $\mathrm{O}_{3}$ formation are absent. Conducive conditions for high rates of ozone production were identified by WDEQ for $\sim 15 \%$ of days in January through March 2011 (MSI, 2011). While the thresholds of required precursor mixing ratios, and consequently emissions, are as yet not determined definitively, the ambient data presented here show the importance of elevated levels of total $\mathrm{NMHC}$ to $\mathrm{O}_{3}$ formation.

\subsection{Source identification using PMF analysis}

Hourly measurements at BSR, collected from October 2010 to March 2011, of speciated NMHC, and other selected parameters, allowed PMF analyses that explored the sensitivity of possible solutions for factor signatures of emission sources to be carried out. Other parameters included $\mathrm{CO}$ (with background subtracted), $\mathrm{CH}_{4}$ (with background subtracted), total NMHC (measured by the Thermo Scientific model 55i analyzer) and $\mathrm{NO}_{\mathrm{x}}$. Preliminary PMF analyses showed that $\mathrm{NO}_{\mathrm{x}}$ generated its own factor, unrelated to those for other species. As the analyses were primarily designed to identify the sources of speciated $\mathrm{NMHC}, \mathrm{NO}_{\mathrm{x}}$ was excluded from subsequent analyses. 
Possible solutions to the PMF analyses were obtained for contributions from two, three, and four factors. Of these solutions, that for three factors was selected, because it yielded factors that are associated with likely emissions sources, was numerically stable using bootstrapping, and produced a solution for which the coefficients of determination $\left(R^{2}\right)$ for all predicted compounds are greater than 0.8 , with 21 out of 24 compounds predicted with $R^{2}>0.88$. All solutions converged and were stable over multiple runs, and bootstrapping in each of 400 runs reproduced the same factor characteristics. The three-factor solution is also favored because while factors 1 and 2 show a positive correlation, contributions from factor 1 , unlike those from factor 2, show no relationship to wind direction. By contrast, the four-factor solution is not stable with respect to bootstrapping, and the two-factor solution has significantly worse coefficients of determination for reproducing individual compound mixing ratios, with 15 of the 24 compounds predicted with $R^{2}$ of $<0.88$. The percentage contributions of each of the three derived factors to the mixing ratio of each constituent compounds are shown in Fig. 5.

The three PMF factor signatures each contain many common component compounds, but at different abundance levels. As previously noted, factors are not necessarily derived from specific emission sources, but can represent groups of sources. Oil and gas developments have numerous continuous and intermittent emission source types, many of which may well have their own unique compositional emissions pattern. Some sources are known to be difficult to quantitatively characterize and/or report, in particular flow-back from well completions and evaporative losses from produced water. Speciated NMHC emissions can, however, be broadly classified as emanating from combustion, fugitive, or product handling sources, e.g., gas dehydration and condensate evaporation. Emission inventory data for the Pinedale Anticline development (February and March 2011 winter inventory) reveals that $\sim 90 \%$ of total VOC emissions $(\sim 400 \mathrm{t})$ are from "natural gas leakage", from source categories coded as tanks, dehydration units, pneumatic pumps, and fugitives (WDEQ, 2014a). Of the estimated $70 \mathrm{t}$ of BTEX (benzene, toluene, ethylbenzene, $m+p$-xylene, and $o$-xylene) emissions for the winter 2011 inventory, $\sim 50 \mathrm{t}$ are assigned to dehydration units, and $\sim 10 \mathrm{t}$ are assigned as fugitive emissions. Thus, based on the emission inventory, while VOC emissions are from many leakage sources, BTEX emissions are dominated by natural gas dehydration.

Figure 5 illustrates the average contribution of each PMF factor to the total derived mixing ratio for each compound across the entire monitoring period. For $\mathrm{CO}$, factor 1 provides the dominant contribution. For speciated $C_{1}$ to $C_{6}$ nonaromatic hydrocarbons, factor 2 dominates; whereas in the heavier hydrocarbon range $\left(\mathrm{C}_{\geq 7}\right)$, up to $o$-xylene, factor 3 becomes dominant. Benzene and ethyne are the only two hydrocarbons that have roughly equivalent contributions from all 3 factors. The average percentage contribution of each

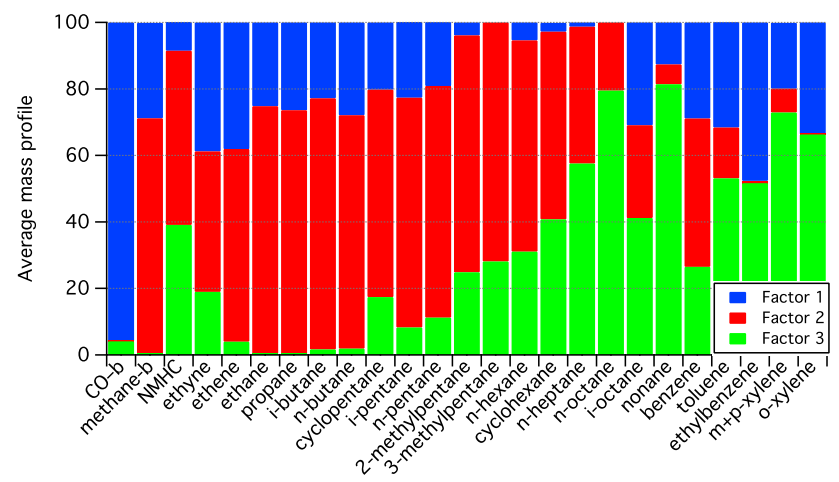

Figure 5. Percentage contribution of PMF factors to the average mixing ratio of each analyzed pollutant ( $-\mathrm{b}$ signifies minus background) from the whole sampling period at Boulder South Road (BSR).

factor to the measured mass of total NMHC are $\sim 10, \sim 50$, and $\sim 40 \%$, for factors 1,2 , and 3 , respectively. However, for the 14 speciated NMHC used for Fig. 6, this weighting is 25,60 , and $15 \%$, respectively. Eight speciated NMHC are excluded from Fig. 6 as they are reported as grouped rather than individual compounds within emission profiles. The contribution of factor 3 weighting declines relative to the other factors due to the absence of these individual reported NMHC species (e.g., nonane). Furthermore, factor 3 is also associated with heavier unidentified NMHC. Figure 6 compares factor profiles with selected emission source profiles.

Designation of factor 1 as combustion (traffic) is supported by the significant contributions of background corrected $\mathrm{CO}$, ethyne, benzene, $i$-octane, toluene, and $o$-xylene, all characteristic of vehicle emissions. Contributions from other engines are possible. However, the diurnal profile for factor 1 shows a morning peak associated with peak traffic flow. Other combustion sources, e.g., drill rigs and compressor stations, in the Pinedale Anticline are reported to have relatively low $\mathrm{CO}$ emission rates while being important sources of $\mathrm{NO}_{\mathrm{x}}$ (Litovitz et al., 2013). Of the three factors, factor 1 displays the least variability, with maximum contributions that are less than five times the average mass values, and also has the lowest overall impact on $\mathrm{O}_{3}$ production, as discussed below. The profile for factor 1 resembles a combination of background, measured at the boundary of the UGRB, and traffic dominated profiles. The traffic profile in Fig. 6a is derived from a combination of profiles of gasoline and diesel vehicle exhaust (Schauer et al., 1999, 2002) with a weighting of $75 \%$ diesel derived from traffic surveys performed within the Pinedale Anticline and Jonah Field developments during 2009/2010. While emissions from traffic are likely to contribute to this factor, the roadside profile at the town of Pinedale also differs somewhat from the distribution derived for factor 1 . This difference of factor 1 from profiles dominated by traffic is due to the additional contributions related 

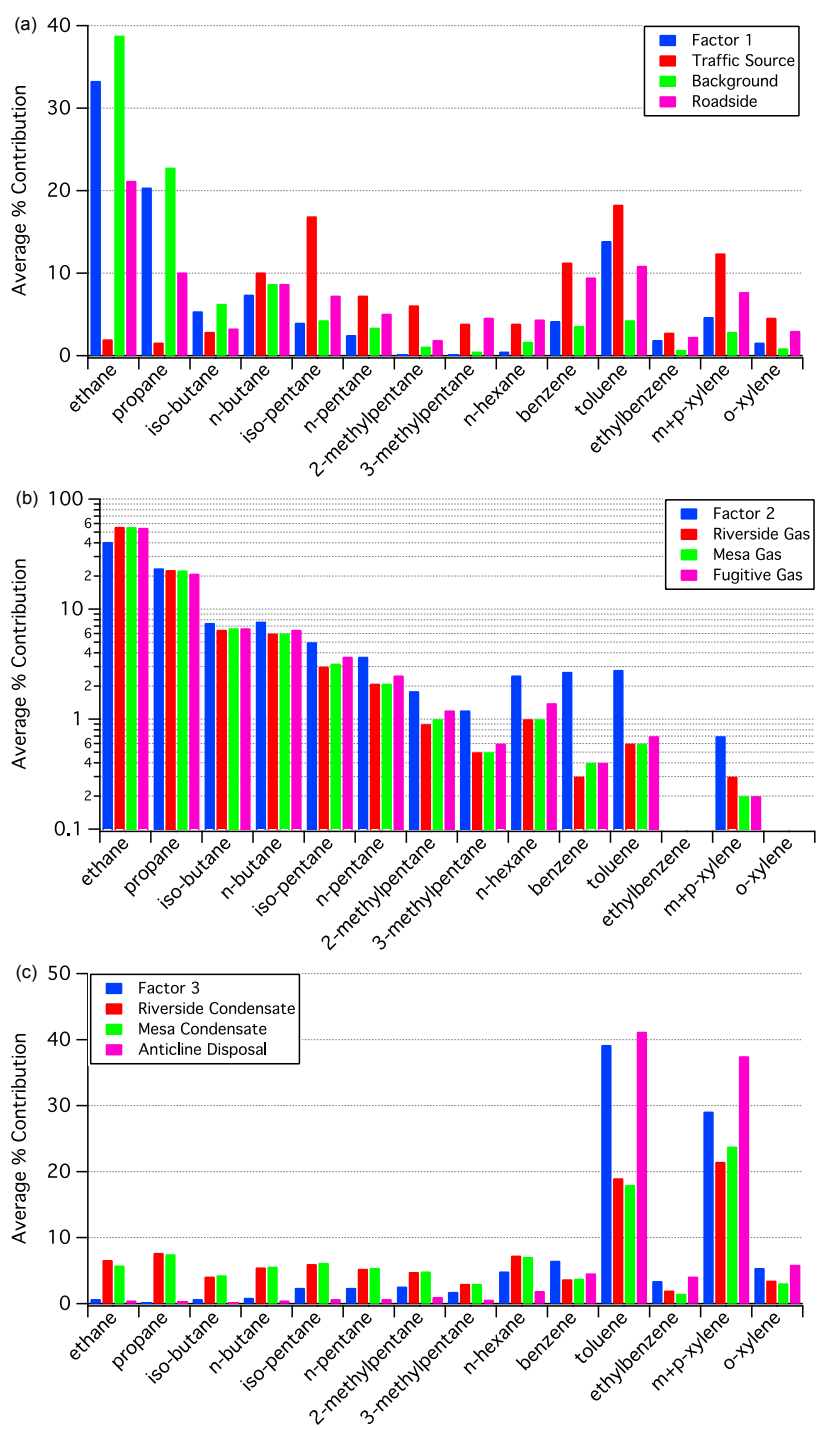

Figure 6. (a) Comparison of factor 1 with emission source profiles as percentage contribution by mass for selected NMHC. (b) Comparison of factor 2 with emission source profiles as percentage contribution by mass for selected NMHC. (c) Comparison of factor 3 with emission source profiles as percentage contribution by mass for selected NMHC.

to factor 2. Such smearing is anticipated to some extent from PMF analysis.

The "fugitive natural gas" designation for factor 2 is largely suggested by the high contributions to its signature from background corrected methane, ethane and propane. The distribution of its component compounds, which closely resembles that for natural gas, includes significant contributions from butanes, pentanes, and several of the compounds also found in factor 1 (e.g., ethene, ethyne, and benzene). For some emission plumes, factor 2 ranges up to $\sim 14$ times the average mass value. Compositional profiles for natural gas are from the Wyoming Oil and Gas Conservation Com- mission (WOGCC) for samples collected from 2001 to 2012 (WOGCC, 2014). The WOGCC averaged profiles for 20 natural gas samples from both the Riverside and Mesa lease areas of the Pinedale Anticline shown in Fig. 6b, are in good agreement with each other and with factor 2 , and clearly demonstrate that natural gas NMHC composition is dominated by light $\left(\leq \mathrm{C}_{5}\right)$ hydrocarbons. Measurements carried out at 190 natural gas production sites in Appalachia, the Gulf Coast, and the Midcontinent and Rocky Mountain regions of the USA, indicate that at many sites pneumatic controllers and pumps are an important source of fugitive gas (Allen et al., 2013). Measurements of fugitive gas in the Pinedale Anticline, from 14 grab samples obtained in this study near operating pneumatic pumps, were used to derive a fugitive emissions profile. This profile, shown in Fig. 6b, matches WOGCC profiles of natural gas. The gas profiles are very similar to factor 2 . However, factor 2 has slightly elevated contributions from BTEX, and this is likely due to emissions from dehydration activities being coincident with those of fugitive natural gas. Sources cannot be distinguished by PMF analysis when they are co-produced at each well site; however, the compositional analysis shown in Fig. 6 clearly identifies fugitive natural gas as the dominant emission source. While it is impossible to differentiate emissions from specific well-pad components, their identity is well known, e.g., pneumatic controllers and dehydration units. Observations show that fugitive natural gas emissions have the greatest impact on NMHC composition at BSR, with strong correlations between many of the light hydrocarbons, as shown in Fig. 7 for methane, ethane, propane, and $n$-butane.

The designation of factor 3 as "fugitive condensate" is supported by high contributions from $\mathrm{C}_{7}$ to $\mathrm{C}_{9}$ compounds, in particular benzene, toluene, ethylbenzene, and xylene isomers (BTEX). Factor 3 also includes significant contributions from nonane, octanes, $n$-heptane, and cyclohexane. The compound distribution closely resembles that for condensate, with the largest contribution from toluene and $m+p$-xylene. The impact of this factor on air samples measured at BSR were most evident during air flow from the southwest. For some emission plumes, factor 3 reaches $\sim 42$ times average mass values. Also shown in Fig. $6 \mathrm{c}$ are WOGCC average profiles for condensate, derived from 20 samples, all with very similar compositions, from both the Riverside and Mesa lease areas. These condensate profiles are dominated by heavier $\left(>\mathrm{C}_{5}\right)$ NMHC constituents. This is also evident for factor 3 , but there are differences in relative contributions. These differences suggest the presence of a significant condensate source, proposed here to be a water treatment and recycling facility (Anticline Disposal facility), located $6 \mathrm{~km}$ west-southwest of the BSR monitoring site, as shown in Fig. 1. Figure $6 \mathrm{c}$ shows a strong similarity of the profile for factor 3 and that for fence line samples next to the water treatment facility. 


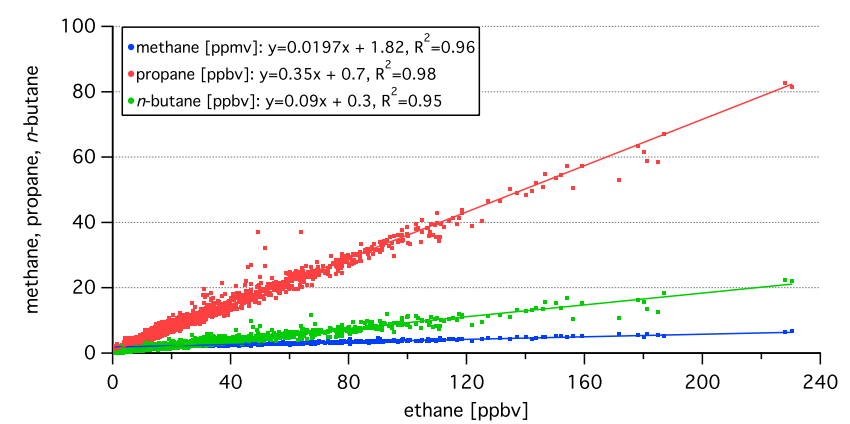

Figure 7. Correlation of methane, propane and $n$-butane with ethane at Boulder South Road (BSR) from 2010 to 2011.

\subsection{Identification of emission source associated with PMF factor 3 at BSR}

The Anticline Disposal facility was constructed to purify and recycle contaminated produced water and hydraulic fracturing flow back water, together with other drilling wastes from the Pinedale Anticline. Water treatment processes at this facility are described in detail by Schafer (2011) and Cox and Schafer (2010). Recycled water for use in hydraulic fracturing is the result of API separator, anaerobic basin, aeration basin, clarifier, and sand filter treatment steps. Aeration of contaminated water within large heated ponds that are open to the environment is expected to enhance evaporative losses from the treated water. Further treatment steps, including a membrane bioreactor, reverse osmosis and electro-coagulation, produce water of sufficient quality for re-injection. Discharge quality water is produced with an additional treatment step of boron ion exchange. Schafer (2011) reports that the contaminated water feed to the facility contains BTEX between 28000 and $80000 \mu \mathrm{g} \mathrm{L}^{-1}$, gasoline organics in the range of 88000 to $420000 \mu \mathrm{g} \mathrm{L}^{-1}$, and diesel organics that range from 77 to $1100 \mu \mathrm{g} \mathrm{L}^{-1}$. One of the three main Pinedale Anticline operators reports between three and four million barrels of their produced water, including flow back water, are treated annually at this facility (US BLM, 2014).

An "in versus out" calculation of emissions is not possible due to a lack of process information. The WDEQ inventory estimates emissions for the 2011 calendar year from the facility as $\sim 49 \mathrm{t}$ of VOC and $\sim 21 \mathrm{t}$ of BTEX, of which $\sim 18 \mathrm{t}$ is reported as benzene. Canister samples taken at the facility fence line indicate a speciated NMHC profile dominated by toluene and xylenes (70\% of total hydrocarbon mass), as shown in Fig. 6c. The average composition distribution of the fence line water treatment facility samples are very similar to that of factor 3 suggesting this facility is the contributing source for factor 3 . However, the possibility of some influence from other condensate emission sources to factor 3, e.g., flow back from completions, cannot be excluded. While quantification of the emission rate is not possible with this data, fence line measurements indicate a BTEX:benzene ratio of $\sim 15: 1$, rather than $\sim 1: 1$ as implied by inventory data. Additionally, fence line mixing ratios up to $992 \mathrm{ppbv}$ of toluene and $911 \mathrm{ppbv}$ of xylene isomers were measured suggesting significant emissions. An inventory derived emission rate of 20 tyear $^{-1}$ of BTEX for the water treatment facility (footprint of 0.08 miles $\left.^{2} ; 0.21 \mathrm{~km}^{2}\right)$ corresponds to an emission intensity of $\sim 250 \mathrm{t} \mathrm{mile}^{-2}\left(\sim 95 \mathrm{t} \mathrm{km}^{-2}\right)$. This value compares to a general intensity for the Pinedale Anticline (footprint of 312 miles $\left.^{2} ; 808 \mathrm{~km}^{2}\right)$ of $\sim 1 \mathrm{t} \mathrm{mile}^{-2}\left(\sim 0.39 \mathrm{t} \mathrm{km}^{-2}\right)$ when emissions from dehydration $\left(258 \mathrm{tyear}^{-1}\right)$, pneumatics $\left(30\right.$ tyear $\left.^{-1}\right)$ and fugitives $\left(73\right.$ tyear $\left.^{-1}\right)$ from the 2045 operating wells in 2011 are combined. Emission inventory estimates therefore show that the facility has a far higher emission rate than the average value for the development. Factor 3 could equally well be labeled "water treatment facility fugitive condensate". While the facility is an important point source of VOC and BTEX, the magnitude of emissions is uncertain. Overall, these data suggest that water treatment operations may have a significant influence on ambient VOC composition and on $\mathrm{O}_{3}$ formation.

\subsection{Spatial variability of speciated NMHC in the UGRB}

Speciated NMHC distributions throughout the UGRB, and in particular in the Pinedale Anticline, were evaluated by carrying out canister sampling surveys. A total of 28 sampling sites were identified, each of which was chosen to be representative of either background, boundary, downwind, upwind, or O\&NG development conditions (Table S2). The surveys in 2010 and 2011 focused on determining differences between mixing ratios at background sites with those observed downwind and close to development activities. Mixing ratios varied significantly, both between sites in each survey and between surveys. Ethane and other speciated NMHC mixing ratios at sites near BLDR and BSR were generally more than twice those found at boundary sites upwind of the development area. At sites closer to development activities, reported ethane mixing ratios were higher, often between $3 \times$ and $10 \times$ those at BLDR and BSR.

Strong correlations of methane, propane and $n$-butane (Fig. 8) with ethane were observed in the data obtained from 255 canister samples collected at 27 sites throughout the UGRB during the period 2010 to 2013. (Samples close to the water treatment facility and production locations with pneumatic pump related fugitive natural gas emissions were excluded from this analysis.) These correlations suggest a commonality of contributing sources and are consistent with the dominance of fugitive natural gas emissions throughout the UGRB. The ratios between these light hydrocarbons are a close match to both those measured at BSR (Fig. 7) and those derived from natural gas composition profiles reported by the WOGCC (Fig. 6b) for samples collected at locations 


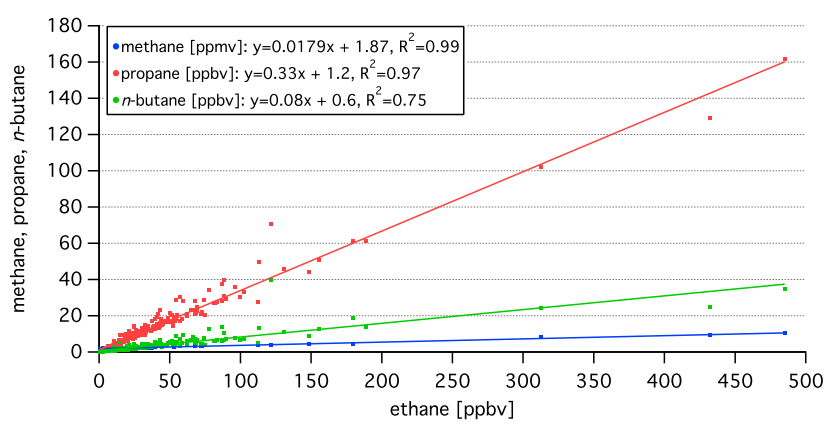

Figure 8. Correlation of methane, propane and $n$-butane with ethane for locations within and around the Pinedale Anticline during 2010-2013 surveys.

ranging from background sites to those downwind of drilling operations. While the ratios of light hydrocarbons are relatively constant, ambient mixing ratios showed considerable variability, reflecting the local influence of meteorology and various O\&NG operations. For example, in 2013 at Middle Crest (Table S2), a site within $\sim 100 \mathrm{~m}$ of active drill rigs, fugitive natural gas signatures with ethane and toluene values of 485 and 11.3 ppbv, respectively, were observed. Similarly, measurements $\sim 300 \mathrm{~m}$ downwind of flow back operations at Mesa South Loop (Table S2) showed fugitive natural gas and condensate signatures with ethane and toluene up to 179 and 202 ppbv, respectively.

During 2011/2012, 12 surveys of $24 \mathrm{~h}$ or 3-day duration were performed at the same 10 sites within and around the Pinedale Anticline boundary. Both Boulder sites are considered as well-mixed downwind sites, often with the lowest speciated NMHC values. While the dominance of alkanes to the total speciated NMHC mass $\left(\mathrm{C}_{2}\right.$ to $\left.\mathrm{C}_{8}\right)$ is consistent, there are enhanced aromatic contributions at three sites, namely Boulder Crest Road, Mesa North, and Mesa South, as shown in Fig. 9. Boulder Crest Road is located $\sim 1.5 \mathrm{~km}$ to the northwest of the water treatment facility, which likely explains enhanced aromatics at this site. The two Mesa sites were in an area of intensive drilling, completion, and production activities. Inventory data identifies dehydration as the most significant source of BTEX emissions, with enhancement relative to aliphatic hydrocarbons, leading, for example, to a much higher BTEX / $n$-hexane ratio than that for the condensate signature shown in Fig. 6c (WDEQ, 2014a). Over $80 \%$ of Pinedale Anticline BTEX production emissions are from dehydration units according to the 2011 winter inventory. Since dehydration emission sources are widely dispersed throughout the Pinedale Anticline, a somewhat uniform distribution of BTEX is anticipated. However, given the high level of activity on the Pinedale Mesa, the influence of emissions from other activities is also possible. For example, completion and flow back operations, neither of which is represented adequately in current emission inventories, are likely to have contributed to elevated BTEX emissions. The

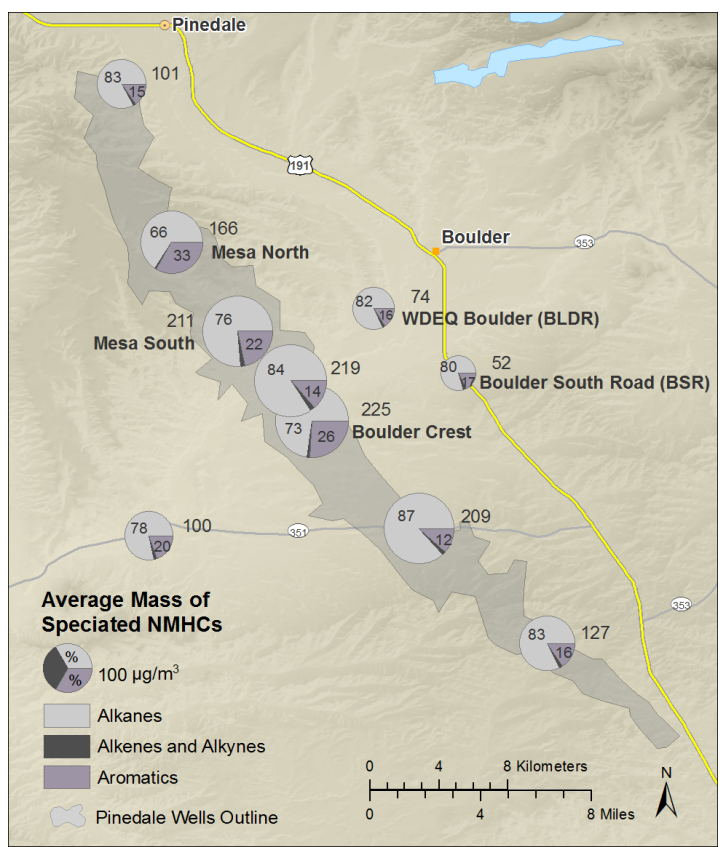

Figure 9. NMHC class distributions for 2011-2012 surveys at 10 sites within and around the Pinedale Anticline (Average mass are scaled as shown relative to the key value of $\left.100 \mu \mathrm{g} \mathrm{m}^{-3}\right)$.

Wyoming DEQ (Department of Environment Quality) inventory reports emissions from the completion category in 2011 as zero for BTEX (WDEQ, 2014a). While the underlying causes of elevated BTEX on the Pinedale Mesa are uncertain, measurements at Boulder Crest and BSR suggest that a nearby water treatment facility causes a significant increase in contributions of higher molecular weight species to NMHC mixing ratios at these sites. Omission of water treatment and completions in inventories could therefore be a significant oversight.

Emission inventory source categories labeled as tanks, pneumatic pumps, and fugitives can be considered as contributing to "fugitive natural gas"; while dehydration unit emissions can equate to "fugitive condensate". Combining estimates of these emissions rates according to this source categorization from the WDEQ emissions inventory for 2011 (WDEQ, 2014a) shows that $\sim 75 \%$ of the inventory is assigned to "fugitive natural gas" and $\sim 25 \%$ to "fugitive condensate". Together, these categories comprise $93 \%$ of the $407 \mathrm{t}$ of VOC and $99 \%$ of the $68 \mathrm{t}$ of BTEX for February and March 2011 in the WDEQ inventory. The predominance of fugitive gas emissions is consistent with the measurements reported here.

\subsection{The importance of each PMF factor to episodic $\mathrm{O}_{3}$ formation}

$\mathrm{O}_{3}$ episodes at both Boulder sites are associated with high total NMHC mixing ratios. Despite being located only $5 \mathrm{~km}$ 
apart, peak $\mathrm{O}_{3}$ differences of $>50 \mathrm{ppbv}$ were evident on both 1 and 2 March 2011 (Fig. 3). These episode days are the least impacted by factor 3 at BSR. The BLDR site is located $7.5 \mathrm{~km}$ north of the water treatment facility (Fig. 1). It is possible that, unlike at BSR, BLDR was impacted by emissions from this facility on these 2 days. The large differences in maximum $\mathrm{O}_{3}$ mixing ratio at the two sites together with the observed hour by hour variations, indicates the localized nature of $\mathrm{O}_{3}$ production and transport and the difficulties of modeling $\mathrm{O}_{3}$ variability and its spatial distribution in the UGRB, particularly as flow patterns in the shallow surface layer below the inversion are as yet only partially characterized (Emery, 2013).

Figure 10 shows time series plots of the total $\mathrm{OH}$ (hydroxyl radical) reactivity of each PMF factor with the $\mathrm{NO}_{\mathrm{x}}$ and $\mathrm{O}_{3}$ mixing ratios, for four representative $\mathrm{O}_{3}$ episode days. Reactivities for measured compounds with $\mathrm{OH}$ were calculated at standard temperature and pressure $(298.15 \mathrm{~K}$ and $1013.25 \mathrm{hPa}$ ) using the recommended $k_{\mathrm{OH}}$ rate coefficients also employed by Gilman et al. (2009), derived from a variety of previous studies (Atkinson, 1986, 1990; Atkinson and Arey, 2003; Atkinson and Aschmann, 1988; DeMore et al., 1997). While the ozone mixing ratio is consistently scaled to 120 (ppbv), $\mathrm{OH}$ reactivity is scaled from $0-10\left(\mathrm{~s}^{-1}\right)$ for 2 March 2011, 0-20 ( $\left.\mathrm{s}^{-1}\right)$ for 5 and 15 March 2011, and 0$40\left(\mathrm{~s}^{-1}\right)$ for 18 February 2011. Spiking of $\mathrm{OH}$ reactivity in Fig. 10 is most prevalent for factor 3. Individual rate coefficient $\left(k_{\mathrm{OH}}\right)$ values are listed in Table S9. Figure S8 shows similar plots for all episode days. For factor $1, \mathrm{OH}$ reactivity is dominated by contributions from $\mathrm{CO}$. The contribution of local methane (total methane minus background methane in the unpolluted troposphere) for factors 1 and 2 accounted for $\sim 2 \%$, and $\sim 5 \%$ of the factor $1 \mathrm{OH}$ reactivity, respectively. Contributions from individual hydrocarbons in factor 2 to total $\mathrm{OH}$ reactivity are relatively uniform because with increasing carbon number, decreases in mixing ratio are offset by higher $k_{\mathrm{OH}}$ values. Factor 3 reactivity contributions are dominated by those from the xylenes and toluene, both of which react relatively rapidly with $\mathrm{OH}$. The plotted reactivities do not account for variations in actinic flux, so would perhaps be best described as potential reactivities that reflect the atmospheric composition.

The plots vary significantly from day to day, but common themes emerge, such as correlated increases in $\mathrm{O}_{3}$ and factor 3 reactivity contributions, often resulting from increases in $m+p$-xylene mixing ratio (and other compounds within the factor 3 profile). However, it is also clear that $\mathrm{O}_{3}$ formation cannot be directly correlated with $\mathrm{OH}$ reactivity, and that NMHC species are mixed into the air parcels after $\mathrm{O}_{3}$ has been formed.

On 18 February, $\mathrm{NO}_{\mathrm{x}}$ levels are somewhat higher than usual so that accumulated $\mathrm{O}_{3}$ is reduced before and after sunrise. A secondary spike in $\mathrm{O}_{3}$ in early evening correlates with a rapid increase in reactivity due to factor 3 . Of the measured factor 3 hydrocarbons, $m+p$-xylene is the most im-
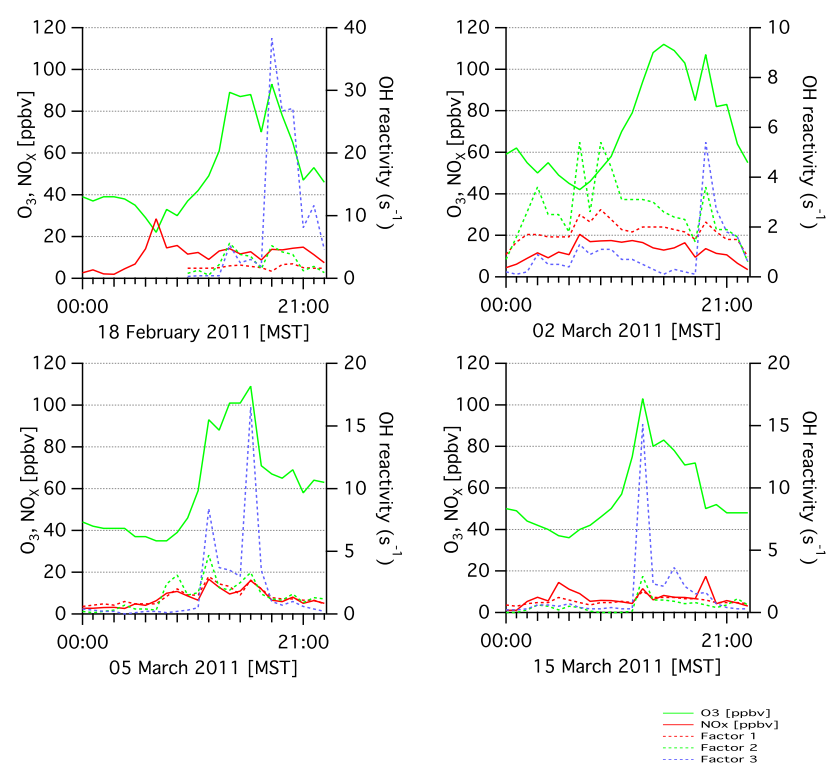

Figure 10. Relationship of PMF factor $\mathrm{OH}$ reactivity, $\mathrm{NO}_{\mathrm{x}}$ and $\mathrm{O}_{3}$ during selected episodes at Boulder South Road (BSR).

portant contributor to $\mathrm{OH}$ reactivity. The measured mixing ratio of $m+p$-xylene in this plume peaks at 37.9 ppbv. Factor 2 contributes most of the $\mathrm{OH}$ reactivity for much of the day on 2 March 2011, when $\mathrm{O}_{3}$ peaks some 50 ppbv higher at BLDR than at BSR, as noted in Fig. 3. Again, as on 18 February 2011, an increase in $m+p$-xylene late in the day, from 0.5 to $5.1 \mathrm{ppbv}$, coincides with an observed $\mathrm{O}_{3}$ increase in early evening. The influence of two-peak reactivity contributions from factor 3 on 5 March 2011 occur when $m+p$ xylene mixing ratios increase from 1.0 to $7.8 \mathrm{ppbv}$ at 12:00 and then, after declining, increase from 3.0 to $16.0 \mathrm{ppbv}$ at 15:00. On 15 March 2011, factor 3 spikes, and there is an associated increase of $m+p$-xylene from 0.4 to $12.3 \mathrm{ppbv}$ at 13:00. Each of these elevated factor 3 contributions coincides with a measured spike in $\mathrm{O}_{3}$. Changes in wind direction could obviously advect factor 3 species to other locations, e.g., BLDR, and thereby affect $\mathrm{O}_{3}$ production rates. Such an event may have occurred on 1 and 2 March 2011, when southwesterlies $\left(\sim 210^{\circ}\right)$ from the direction of the water treatment facility were reported at BLDR, and higher $\mathrm{O}_{3}$ mixing ratios were observed.

In summary, the time series plots in Fig. 10 (and Fig. S8) suggest that factor 3 emission sources, associated with high NMHC values, have a significant role in $\mathrm{O}_{3}$ formation in surface air impacting the Boulder area downwind of the Pinedale Anticline. Toluene and the xylenes are the principal compounds that lead to increases in factor 3 total reactivity and hence in $\mathrm{O}_{3}$ production potential. These compounds alone frequently contribute more than $50 \%$ of $\mathrm{OH}$ reactivity for factor 3. It should be noted that other unreported compounds are likely to be present within this emission source. Trimethylbenzenes are also expected to add significantly to 
factor 3 reactivity, but unfortunately, though known to be present in the air samples that contain xylenes, their mixing ratios could not be accurately assessed. Table S9 contrasts reactivity, derived from the sum of pseudo-first order rate coefficients of speciated $\mathrm{NMHC}, \mathrm{CH}_{4}$, and $\mathrm{CO}$ with $\mathrm{OH}$, for 2 different days at 18:00. Total reactivity at 18:00 on 20 February $\left(1.89 \mathrm{~s}^{-1}\right)$, with relatively low $\mathrm{O}_{3}$ and factor 3 contributions, is considerably lower than at 18:00 on 18 February $\left(49.42 \mathrm{~s}^{-1}\right)$, with relatively high $\mathrm{O}_{3}$ and factor 3 contributions (Fig. 10). The listed values also lead to the conclusion that neither $\mathrm{CO}$ nor $\mathrm{CH}_{4}$ are important contributors to $\mathrm{OH}$ reactivity during $\mathrm{O}_{3}$ episodes.

Wintertime $\mathrm{O}_{3}$ episodes in the UGRB and the Uintah Basin share many important common characteristics (Oltmans et al., 2014). Episodic $\mathrm{O}_{3}$ production in both basins is associated with high $\mathrm{NMHC}$ levels and moderate $\mathrm{NO}_{\mathrm{x}}$. A key difference is that unlike the Uintah basin, $\mathrm{O}_{3}$ in the UGRB can be spatially highly variable with large gradients over small distances. In the UGRB, our results show that fugitive condensate material, and in particular its methylated aromatic constituents, frequently plays an important role in determining NMHC reactivity towards $\mathrm{OH}$. A similar conclusion, derived from a numerical modeling study, has recently been reported for the Uintah Basin (Ahmadov et al., 2015).

\section{Summary and conclusions}

The pollutant profile observed in the winter of 2011 at a monitoring site close to the Pinedale Anticline natural gas field in Sublette County, Wyoming, differs from that measured in winter 2012, when significantly lower ambient total NMHC mixing ratios are associated with a lack of $\mathrm{O}_{3}$ episodes. During 2011, numerous localized $\mathrm{O}_{3}$ episodes were evident in the Boulder area of the UGRB, sometimes with significant gradients in $\mathrm{O}_{3}$ mixing ratios over relatively short distances.

Total NMHC mixing ratios are dominated by compounds associated with fugitive emissions of natural gas and condensate. $\mathrm{C}_{2}$ to $\mathrm{C}_{4}$ alkanes and $\mathrm{C}_{7}$ to $\mathrm{C}_{8}$ aromatics are the most abundant speciated NMHC. PMF analyses revealed three contributing factors that were identified with different emission source types: factor 1, combustion/traffic; factor 2, fugitive natural gas; and factor 3, fugitive condensate. The attribution of the PMF factors is supported by their close similarity to independent emission source profiles, in particular, for sources related to O\&NG activities. In addition to fugitive natural gas, factor 2 includes emissions from dehydration emissions, indicated by BTEX contributions. While factor 3 is noted as fugitive condensate, it could equally well be designated as water treatment emissions. Factor profile and meteorological data suggest that the water treatment facility is a point source for emissions of factor 3. Sampling surveys downwind of this facility show a condensate type sig- nature that matches factor 3 with significantly elevated levels of toluene and $m+p$-xylene.

Surveys of speciated NMHC within the UGRB reveal fugitive emission of natural gas to be the dominant source of both methane and $\mathrm{C}_{2}$ to $\mathrm{C}_{4} \mathrm{NMHC}$ for all of the 28 sampling sites. At some sites the relative contribution from alkanes (fugitive natural gas) to total NMHC mass is reduced due to enhanced aromatic contributions. Two areas had relatively elevated levels of aromatic compounds, an area of intensive exploration activity on the Pinedale Mesa, and close to a water treatment facility. Elevated levels of aromatics at the Pinedale Mesa may have resulted from a variety of sources including dehydration and flow back operations during well completions. Emissions from a water treatment facility can influence NMHC measurements at the BSR site, and other sampling locations in the Boulder area of the Pinedale Anticline.

\section{The Supplement related to this article is available online at doi:10.5194/acp-15-3527-2015-supplement.}

Author contributions. R. A. Field designed the experimental approach for the study. R. A. Field and J. Soltis performed data collection and validation activities. M. C. McCarthy performed the PMF analysis. R. A. Field interpreted the results of the study and prepared the manuscript with support from all co-authors, in particular D. C. Montague.

Acknowledgements. Our sincere thanks goes to Peter Dumitrean for assistance when setting-up the VOC system. Financial support from the University of Wyoming School of Energy Resources and the Pinedale Anticline Project Office for the PASQUA study, whose results we present here, are appreciated. We also acknowledge WDEQ, which provided data, external auditors for routine parameter measurements, and PASQUA administrative oversight, as well as funding of the MAPA project. We thank all the individuals and their respective organizations involved in canister deployment, namely the following: Sublette County Conservation District (Meghann Durbrow and Loren Racich); Sublette County Health District (Keith Raney); Wyoming BLM (Tim Zebulske, Kyle Schumacher, Brian Roberts, Cindi Etcheverry and Janet Bellis); USFS (Ted Porwoll); Citizens United for Responsible Energy Development (Perry Walker, Bev Sharp, Carmel Kail, Tina Rock, Elaine Crumpley, and Mary Lynn Worl); WDEQ (Jennifer Frazier, Ken Rairigh and Brandi O'Brien); Town of Pinedale (Patty Racich, Dave Racich, and Dave Hohl); Shell (Nancy Feck, Jasmine Allison, and Aimee Davidson); BP (Don Brooks); and QEP (Kevin Williams). Thanks also to ShihMing Huang for producing maps for the manuscript. Finally the comments and support of Richard (Dick) Derwent are appreciated.

Edited by: P. Monks 


\section{References}

Adgate, J. L., Goldstein, B. D., and McKenzie, L. M.: Potential public health hazards, exposures and health effects from unconventional natural gas development, Environ. Sci. Technol., 48, 8307-8320, doi:10.1021/es404621d, 2014.

Ahmadov, R., McKeen, S., Trainer, M., Banta, R., Brewer, A., Brown, S., Edwards, P. M., de Gouw, J. A., Frost, G. J., Gilman, J., Helmig, D., Johnson, B., Karion, A., Koss, A., Langford, A., Lerner, B., Olson, J., Oltmans, S., Peischl, J., Pétron, G., Pichugina, Y., Roberts, J. M., Ryerson, T., Schnell, R., Senff, C., Sweeney, C., Thompson, C., Veres, P. R., Warneke, C., Wild, R., Williams, E. J., Yuan, B., and Zamora, R.: Understanding high wintertime ozone pollution events in an oil- and natural gasproducing region of the western US, Atmos. Chem. Phys., 15, 411-429, doi:10.5194/acp-15-411-2015, 2015.

Allen, D. T., Torres, V. M., Thomas, J., Sullivan, D. W., Harrison, M., Hendler, A., Herndon, S. C., Kolb, C. E., Fraser, M. P., Hill, A. D., Lamb, B. K., Miskimins, J., Sawyer, R. F., and Seinfeld, J. H.: Measurements of methane emissions at natural gas production sites in the United States, P. Natl. Acad. Sci., 110, 1776817773, doi:10.1073/pnas.1304880110, 2013.

Atkinson, R.: Kinetics and mechanisms of the gas-phase reactions of the hydroxyl radical with organic-compounds under atmospheric conditions, Chem. Rev., 86, 69-201, 1986.

Atkinson, R.: Gas-phase tropospheric chemistry of organic compounds. A review, Atmos. Environ., 24A, 1-41, 1990.

Atkinson, R. and Arey, J.: Atmospheric degradation of volatile organic compounds, Chem. Rev., 103, 4605-4638, 2003.

Atkinson, R. and Aschmann, S. M.: Kinetics of the reactions of acenaphthene and acenaphthylene and structurally related aromatic compounds with $\mathrm{OH}$ and $\mathrm{NO}_{3}$ radicals, $\mathrm{N}_{2} \mathrm{O}_{5}$ and $\mathrm{O}_{3}$ at $296 \pm 2$ K, Int. J. Chem. Kinet., 20, 513-539,1988.

Brandt, A. R., Heath, G. A., Kort, E. A., O’Sullivan, F. O., Pétron, G., Jordaan, S. M., Tans, P., Wilcox, J., Gopstein, A. M., Arent, D., Wofsy, S., Brown, N. J., Bardley, R., Stucky, G. D., Eardley, D., and Harris, R.: Methane leaks from North American natural gas systems, Science, 343, 733-735, 2014.

Broadway, G. and Tipler, A.: Ozone precursor analysis using a Thermal Desorption-GC system, PerkinElmer Gas Chromatography White Paper No. 008880B_01, Perkin Elmer, 2012.

Brown, S. G., Frankel, A., and Hafner, H. R.: Source apportionment of VOCs in the Los Angeles area using positive matrix factorization, Atmos. Environ., 41, 227-237, 2007.

Buzcu, B. and Fraser, M. P.: Comparison of VOC emissions inventory data with source apportionment results for Houston, TX, Atmos. Environ., 42, 5032-5043, 2008.

Carter, W. P. and Seinfeld, J. H.: Winter ozone formation and VOC incremental reactivities in the Upper Green River Basin of Wyoming, Atmos. Environ., 50, 255-266, 2012.

Caulton, D. R., Shepson, P. B., Santoro, R. L., Sparks, J. P., Howarth, R. W., Ingraffea, A. R., Cambaliza, M. O. L., Sweeney, C., Davis, K. J., Stirm, B. H., Montzka, S. A., and Miller, B. R.: Toward a better understanding and quantification of methane emissions from shale gas development, P. Natl. Acad. Sci., 111, 6237-6242, 2014.

Colburn, T., Schultz, K., Herrick, L., and Kwiatkowski, C.: An exploratory study of air quality near natural gas operations, Hum. Ecol. Risk Assess. Int. J., 20, 86-105, doi:10.1080/10807039.2012.749447, 2014.
Cox, L. and Schafer, L.: A working model for oil and gas produced water treatment. Energy resources and produced waters conference, 25 to 26 May 2010, Laramie Wyoming, accessed through the University of Wyoming WyoCast OnDemand interface at: http://wyocast.uwyo.edu/WyoCast/Play/ 27449dccec254addb46c72528606a76d (last access: 1 September 2014), 2010.

DeMore, W. B., Sander, S. P., Golden, D. M., Hampson, R. F., Kurylo, M. J., Howard, C. J., Ravishankara, A. R., Kolb, C. E., and Molina, M. J.: Chemical kinetics and photochemical data for use in stratospheric modeling: Evaluation number 12, JPL Publ. 97-4, 1-266, NASA, Pasadena, California, 1997.

Dernie, J. and Dumitrean, P.: UK hydrocarbon network annual report for 2012, Report by AEA Technology ED 47833/ED46645, 2013.

Derwent, R. G., Dernie, J., Dollard, G. J., Dumitrean, P., Mitchell, R. F., Murrells, T. P., Telling, S. P., and Field, R. A.: Twenty years of continuous high time resolution volatile organic compound monitoring in the United kingdom from 1993 to 2012, Atmos. Environ., 99, 239-247, 2014.

Dollard, G. J., Davies, T. J., Jones, B. M. R., Nason, P. D., Chandler, J., Dumitrean, P., Delaney, M., Watkins, D., and Field, R. A.: The UK hydrocarbon monitoring network, Chap. 3, 37-50, Volatile organic compounds in the atmosphere, ISBN 0-85404215-61995, edited by: Hester, R. E. and Harrison, R. M., Royal Society of Chemistry, Cambridge, UK, 1995.

Edwards, P. M., Young, C. J., Aikin, K., deGouw, J., Dubé, W. P., Geiger, F., Gilman, J., Helmig, D., Holloway, J. S., Kercher, J., Lerner, B., Martin, R., McLaren, R., Parrish, D. D., Peischl, J., Roberts, J. M., Ryerson, T. B., Thornton, J., Warneke, C., Williams, E. J., and Brown, S. S.: Ozone photochemistry in an oil and natural gas extraction region during winter: simulations of a snow-free season in the Uintah Basin, Utah, Atmos. Chem. Phys., 13, 8955-8971, doi:10.5194/acp-13-8955-2013, 2013.

Edwards, P. M., Brown, S. S., Roberts, J. M., Ahmadov, R., Banta, R. M, de Gouw, J. A., Dubeì, W. P., Field, R. A., Flynn, J. H., Gilman, J. B., Graus, M., Helmig, D., Koss, A., Langford, A. O., Lefer, B. L., Lerner, B. M., Li, R., Li, S. M., McKeen, S. A., Murphy, S. M., Parrish, D. D., Senff, C. J., Soltis, J., Stutz, J., Sweeney, C., Thompson, C. R., Trainer, M. K., Tsai, C., Veres, P. R., Washenfelder, R. A., Warneke, C., Wild, R. J., Young, C. J., Yuan, B., and Zamora, R.: Unconventional photochemistry underlying winter ozone in an oil and gas producing region, Nature, 514, 351-354, doi:10.1038/nature13767, 2014.

Efron, B.: The jackknife, the bootstrap and other resampling plans, Society for Industrial and Applied Mathematics, Philadelphia, PA, ISBN 978-0-89871-179-0, 1982.

Efron, B. and Tibshirani, R. J.: An introduction to the bootstrap, Chapman \& Hall, New York, ISBN-13: 978-041204231, 1993.

Emery, B.: An analysis of wintertime surface wind fields in the Upper Green River Basin of Sublette County, Wyoming, University of Wyoming ProQuest Dissertations and Theses, Publication Number AAT 1543752, ISBN 9781303315442, available at: http://www.proquest.com/products-services/dissertations/, Thesis (M.S.), 2013.

Field, R. A., Soltis, J., and Murphy, S.: Air quality concerns of unconventional oil and natural gas production, Environ. Sci. Processes Impacts, 16, 954-969, 2014. 
Francis, R.: Personal Communication regarding performance of Thermo Scientific model 55i analyzer, Thermo Scientific, 2014.

Gilman, J. B., Kuster, W. C., Goldan, P. D., Herndon, S. C., Zahniser, M. S., Tucker, S. C., Brewer, W. A., Lerner, B. M., Williams, E. J., Harley, R. A., Fehsenfeld, F. C., Warneke, C., and de Gouw, J. A.: Measurements of volatile organic compounds during the 2006 TexAQS/GoMACCS campaign: Industrial influences, regional characteristics, and diurnal dependencies of the OH reactivity, J. Geophys. Res., 114, D00F06, doi:10.1029/2008JD011525, 2009.

Gilman, J. B., Lerner, B. M., Kuster, W. C., and de Gouw, J. A.: Source signature of volatile organic compounds from oil and natural gas operations in Northeastern Colorado, Environ. Sci. Technol., 47, 1297-1305, 2013.

Helmig, D., Thompson, C. R., Evans, J., Boylan, P., Hueber, J., and Park, J.-H.: Highly elevated atmospheric levels of volatile organic compounds in the Uintah Basin, Utah, Environ. Sci. Technol., 48, 4707-4715, 2014.

Karion, A., Sweeney, C., Pétron, G., Frost, G., Hardesty, R. M., Kofler, J., Miller, B. R., Newberger, T., Wolter, S., Banta, R., Brewer, A., Dlugokencky, E. J., Lang, P. M., Montzka, S. A., Schnell, R., Tans, P., Trainer, M., Zamora, R., and Conley, S.: Methane emissions estimate from airborne measurements over a western United States natural gas field, Geophys. Res. Lett., 40, 4393-4397, doi:10.1002/grl.50811, 2013.

Litovitz, A., Cutright, A., Abramzon, S., Burger, N., and Samaras, C.: Estimation of regional air-quality damages from Marcellus Shale natural gas extraction in Pennsylvania, Environ. Res. Lett., 8, 014017, doi:10.1088/1748-9326/8/1/014017, 2013.

Martin, R., Moore, K., Mansfield, M., Hill, S., Harper, K., and Shorthill, H.: Uintah Basin winter ozone and air quality study, Report, University of Utah, available at: http://rd.usu.edu/ files/uploads/ubos_2010-11_final_report.pdf (last access: 14 August 2014), 2011.

McCarthy, M. C., Aklilu, Y. A., Brown, S. G., and Lyder, D. A.: Source apportionment of volatile organic compounds measured in Edmonton, Alberta, Atmos. Environ., 81, 504-516, 2013.

McKenzie, L. M., Witter, R. Z., Newman, L. S., and Adgate, J. L.: Human health risk assessment of air emissions from development of unconventional natural gas resources, Sci. Total Environ., 424, 79-87, 2012.

McKenzie, L. M., Guo, R., Witter, R. Z., Savitz, D. A., Newman, L. S., and Adgate, J. L.: Birth outcomes and maternal residential proximity to natural gas development in rural Colorado, Environ. Health. Persp., 122, 412-417, 2014.

Moore, C. W., Zielinska, B., Pétron, G., and Jackson, R. B.: Air impacts of increased natural gas acquisition, processing, and use: a critical review, Environ. Sci. Technol., 48, 8349-8359, doi:10.1021/es4053472, 2014.

MSI (Meteorological Solutions, Inc.): Final Report, 2011 Upper Green River Winter Ozone Study, available at: http: //sgirt.webfactional.com/filesearch/content/AirQualityDivision/ Programs/Ozone/WinterOzone-WinterOzoneStudy/2011_ UGWOS-Monitoring-Final-Report.pdf, Report, 2011.

MSI (Meteorological Solutions, Inc.): Final Report, 2012 Upper Green River Winter Ozone Study, available at: http: //sgirt.webfactional.com/filesearch/content/AirQualityDivision/ Programs/Ozone/WinterOzone-WinterOzoneStudy/2012 UGWOS-Monitoring-Final-Report.pdf, Report, 2012.
MSI (Meteorological Solutions, Inc.): Final Report, 2013 Upper Green River Winter Ozone Study, MSI and T\&B Systems, available at: http://sgirt. webfactional.com/filesearch/content/AirQualityDivision/ Programs/Ozone/WinterOzone-WinterOzoneStudy/2013_ UGWOS-Monitoring-Final-Report.pdf, Report, 2013.

MSI (Meteorological Solutions, Inc.): Final Report, 2014 Upper Green River Winter Ozone Study, available at: http: //sgirt.webfactional.com/filesearch/content/AirQualityDivision/ Programs/Ozone/WinterOzone-WinterOzoneStudy/2014_ UGWOS-Monitoring-Final-Report.pdf, Report, 2014.

Norris, G., Vedantham, R., Wade, K. S., Brown, S. G., Prouty, J. D., and Foley, C.: EPA positive matrix factorization (PMF) 3.0 fundamentals and user guide. Report by the National Exposure Research Laboratory, Sonoma Technology Inc. and Lockheed Martin Systems Engineering Center, EP-D-05-004; STI-907045.053347-UG, 2008.

Oltmans, S., Schnell, R., Johnson, B., Pétron, G., Mefford, T., and Neely, R.: Anatomy of wintertime ozone associated with oil and natural gas extraction activity in Wyoming and Utah, Elem. Sci. Anth., 2, 000024, doi:10.12952/journal.elementa.000024, 2014.

Paatero, P.: Least squares formulation of robust non-negative factor analysis, Chemometr. Intell. Lab., 37, 23-35, doi:10.1016/S0169-7439(96)00044-5, 1997.

Paatero, P. and Tapper, U.: Positive matrix factorization: a nonnegative factor model with optimal utilization of error estimates of data values, Environmetrics, 5, 111-126, 1994.

Pétron, G., Frost, G., Miller, B. R., Hirsch, A. I., Montzka, S. A., Karion, A., Trainer, M., Sweeney, C., Andrews, A. E., Miller, L., Kofler, J., Bar-Ilan, A., Dlugokencky, E. J., Patrick, L., Moore Jr., C. T., Ryerson, T. B., Siso, C., Kolodzey, W., Lang, P. M., Conway, T., Novelli, P., Masarie, K., Hall, B., Guenther, D., Kitzis, D., Miller, J., Welsh, D., Wolfe, D., Neff, W., and Tans, P.: Hydrocarbon Emissions Characterization in the Colorado Front Range: A Pilot Study, J. Geophys. Res., 117, D04304, doi:10.1029/2011JD016360, 2012.

Poirot, R. L., Wishinski, P. R., Hopke, P. K., and Polissar, A. V.: Comparative application of multiple receptor methods to identify aerosol sources in northern Vermont, Environ. Sci. Technol., 35, 4622-4636, 2001.

Rappenglück, B., Ackermann, L., Alvarez, S., Golovko, J., Buhr, M., Field, R. A., Soltis, J., Montague, D. C., Hauze, B., Adamson, S., Risch, D., Wilkerson, G., Bush, D., Stoeckenius, T., and Keslar, C.: Strong wintertime ozone events in the Upper Green River basin, Wyoming, Atmos. Chem. Phys., 14, 4909-4934, doi:10.5194/acp-14-4909-2014, 2014.

Schauer, J. J., Kleeman, M. J., Cass, G. R., and Simoneit, B. R. T.: Measurement of emissions from air pollution sources $C_{1}$ through $\mathrm{C}_{30}$ organic compounds from medium duty diesel trucks, Environ. Sci. Technol., 33, 1578-1587, 1999.

Schauer, J. J., Fraser, M. P., Cass, G. R., and Simoneit, B. R. T.: Measurement of emissions from air pollution sources $C_{1}-C_{32}$ organic compounds from gasoline-powered motor vehicles, Environ. Sci. Technol., 36, 1169-1180, 2002.

Schafer, L.: Water recycling and purification in the Pinedale Anticline Field: Results from the Anticline Disposal Project, SPE 141448, paper presented at Society of Petroleum Engineers Conference, Houston, TX, 21-23 March, 2011. 
Schnell, R. C., Oltmans, S. J., Neely, R. R., Endres, M. S., Molenar, J. V., and White, A. B.: Rapid photochemical production of ozone at high concentrations in a rural site during winter, Nat. Geosci., 2, 120-122, 2009.

Soltis, J. and Field, R. A.: Upper Green River Ozone Investigation (O3i), mobile laboratory monitoring of ozone precursors at Big Piney, Luman Road, Boulder South road, Pinedale and Olson Ranch monitoring sites 2009, Report, University of Wyoming, available at: http://www-das.uwyo.edu/ozone/index. html (last access: 25 March 2015), 2009.

Soltis, J. and Field, R. A.: Pinedale Anticline Spatial Air Quality Assessment (PASQUA), mobile laboratory monitoring of ozone precursors at Boulder South Road site 2010-2011, Report, University of Wyoming, available at: http://www-das.uwyo.edu/ ozone/index.html (last access: 5 August 2014), 2011a.

Soltis, J. and Field, R. A.: Pinedale Anticline Spatial Air Quality Assessment (PASQUA), 2010-2011 spatial distribution surveys, Report, University of Wyoming, available at: http://www-das. uwyo.edu/ozone/index.html (last access: 5 August 2014), 2011 b.

Soltis, J. and Field, R. A.: Pinedale Anticline Spatial Air Quality Assessment (PASQUA), mobile laboratory monitoring of ozone precursors at Boulder South Road site 2011-2012, Report, University of Wyoming, available at: http://www-das.uwyo.edu/ ozone/index.html (last access: 5 August 2014), 2012a.

Soltis J. and Field R.A.: Pinedale Anticline Spatial Air Quality Assessment (PASQUA), 2011-2012 spatial distribution surveys, Report, University of Wyoming, available at: http://www-das. uwyo.edu/ozone/index.html (last access: 5 August 2014), 2012 b.

Song, X. H., Polissar, A. V., and Hopke, P. K.: Sources of fine particle composition in the northeastern U.S., Atmos. Environ., 35, 5277-5286, 2001.

US BLM (US Bureau of Land Management): Annual Operator Meetings, available at: http://www.blm.gov/wy/st/en/ field_offices/Pinedale/anticline/airwatermtg.html (last access: 1 September 2014), 2014.

US Census Bureau: American Community Survey, US Department of Commerce, Economics and Statistics Administration, Suitland, MD, available at: http://www.census.gov/acs/www/ (last access: 24 March 2015), Report, 2010.

US Department of Energy: Modern shale gas development in the United States: A primer, Contract DE-FG26-04NT15455, 2009, Report by Office of Fossil Energy National Energy Technology Laboratory, 2009.
US EIA (US Energy Information Administration): 2009 US Crude Oil, Natural Gas and Natural Gas Liquids Proved Reserves, top100 fields, 2010, Office of Oil, Gas, and Coal Supply Statistics U.S. Department of Energy, Washington, DC 20585, available at: http://www.eia.gov/oil_gas/rpd/topfields.pdf (last access: 24 March 2015), Report, 2010.

US EIA (US Energy Information Administration): 2012 Annual energy outlook, Office of Integrated and International Energy Analysis US Department of Energy, Washington, DC 20585, available at: http://www.eia.gov/forecasts/aeo/pdf/0383(2012) .pdf (last access: 24 March 2015), Report, 2012.

US EIA (US Energy Information Administration): Annual energy outlook 2014 Early Release Overview, Office of Integrated and International Energy Analysis US Department of Energy, Washington, DC 20585, available at: http://www.eia.gov/forecasts/ aeo/er/pdf/0383er(2014).pdf (last access: 24 March 2015), Report, 2014.

Warneke, C., Geiger, F., Edwards, P. M., Dube, W., Pétron, G., Kofler, J., Zahn, A., Brown, S. S., Graus, M., Gilman, J. B., Lerner, B. M., Peischl, J., Ryerson, T. B., de Gouw, J. A., and Roberts, J. M.: Volatile organic compound emissions from the oil and natural gas industry in the Uintah Basin, Utah: oil and gas well pad emissions compared to ambient air composition, Atmos. Chem. Phys., 14, 10977-10988, doi:10.5194/acp14-10977-2014, 2014.

WDEQ (Wyoming Department of Environmental Quality): Actual Emission Inventories, available at: http: //deq.wyoming.gov/aqd/emission-inventories/resources/ annual-and-winter-ugrb-emissions/ (last access: 4 September 2014), 2014a.

WDEQ (Wyoming Department of Environmental Quality): Wyoming Visibility Monitoring Network, available at: http://www.wyvisnet.com (last access: 4 September 2014), 2014b.

WOGCC (Wyoming Oil and Gas Conservation Commission): Gas/Water Analysis, available at: http://wogcc.state.wy.us/ AnalysisMenu.cfm?Skip='Y' \&oops=ID42520 (last access: 5 August 2014), 2014. 